\title{
TESTING THE BOUNDARIES OF THE RELEVANT MARKET IN THE COMPETITION POLICY
}

\author{
Milan Kostic* \\ Faculty of Economics, University of Kragujevac, Kragujevac, Serbia
}

The concept of the relevant market is very important for the competition policy. The assessment of the market power of the economic entities operating on a relevant market depends on the market size. The relevant market has two dimensions - the production and the geographic ones - hence, there are a relevant product market and a relevant geographic market. The purpose of the paper is to show the possible ways of determining the relevant market boundaries, in an explicit and systematic way, by applying appropriate tests, and on the example of the specific Serbian market. In the paper, two important tests to determine the boundaries of the market have been applied: the Price Correlation Test and the Goods Physical Movement Test (the Elzinga-Hogarty test). The tests are very useful in situations where researchers only possess secondary data and want to determine the boundaries of the market based on them. The disadvantages of the tests, which of course exist, do not diminish their importance; therefore, they are very useful and recommended for determining the scope of the market.

Keywords: relevant market, competition policy, Price Correlation Test, Elzinga-Hogarty test

JEL Classification: D47, L40, K21

\section{INTRODUCTION}

Defining the relevant market boundaries is a necessary prerequisite for determining the market power of corporations and is, therefore, the first stage in the analysis of competitive conditions (Xianlin, 2008, 541). A differently defined relevant market implies a different assessment of corporations' market power, which results in the same firm having a different market power in different proceedings before the

\footnotetext{
* Correspondence to: M.Kostic, Faculty of Economics, University of Kragujevac; D. Pucara 3, 34000 Kragujevac, Srbija; e-mail:mkostic@kg.ac.rs
}

anti-monopoly authorities (ABA, 2005, 53-54). If the boundaries of the relevant market are narrowly defined, individual firms are likely to enjoy a greater market share and, consequently, a greater market power than in a broadly defined market (Stadler, 2009, 1062). The assessment of the relevant market boundaries precisely depends on defining the boundaries (Kostić, 2007, 105). It follows that the phenomenon of the relevant market sets out a framework within which to analyze the conditions of competition and apply the rules of the protection of competition, in a systematic and comprehensive manner, so we can say that it belongs to the anti-monopoly dogma, which is 
becoming increasingly important today (ACPC, 2009, 83; Lopatka, 2011, 69).

Before defining the boundaries of the relevant market, two tasks are set. The first is to define the line of the products that are substitutable and the geographic areas in which the substitutability is achieved; and the second one, which refers to the identifying of the market participants, their market share, and the degree of the market concentration resulting from it (DOJ \& FTC, 2010, 7).

The subject of this paper is to test the boundaries of the relevant market on the example of the sector of the Serbian economy. In this way, we will try to show the importance of this segment of the economic analysis for the competition policy. The aim is to provide a complete picture of what it is like to define the relevant market boundaries by applying appropriate economic tests. Starting from the defined subject and the aim of the research, we are going to test the research hypotheses to determine the boundaries of the relevant market. The main research hypothesis is:

$\mathrm{H} 0$ : The market of edible oils can be treated as a single relevant market, which covers the entire territory of the Republic of Serbia.

The two additional hypotheses are derived from this one, and they relate to the individual dimensions of the relevant market:

H1 : Edible oil alone constitutes a relevant product market.

$\mathrm{H} 2$ : The relevant geographic market in which edible oil is sold is the territory of the Republic of Serbia.

According to the defined subject, aim, and scientific hypotheses, the research was performed on the basis of the secondary data that were available in the statistical publications and databases of the relevant national and international institutions. The resulting data were used in accordance with the procedures requiring techniques for defining the relevant market boundaries, and thus the research hypotheses were tested.
The paper is so designed to comprise five sections. In addition to the introduction, the paper presents the theoretical background of the concept of the relevant market, the description of the methodology of the data collection, the results of the research with a discussion and the concluding remarks with the limitations of the research and the paper itself.

\section{THEORETICAL BACKGROUND}

In terms of defining the concept, and therefore the market boundaries, the views of economists have changed over time, which has particularly been complicated by the emergence of the theory of imperfect and monopolistic competition in the midtwentieth century (Werden, 1992, 126). The first texts on the relevant market and its boundaries appeared during the 1970s and the 1980s. Afterwards, the concept was introduced in the economic literature and was primarily associated with the competition policy (Massey, 2000, 313). Simultaneously with the appearance of this concept, the economic analysis in the area of the regulations of the state started to extensively be applied (Kostić, 2012, 250).

As an area where competition confronts, the relevant market has two dimensions - the production and the geographic ones, which means that it must be defined in terms of the range and in terms of the area in which the range is sold. This implies that the relevant market includes the relevant product market and the relevant geographic market (Labus, 2008, 52). The relevant product market is mainly defined as a set of goods and services that consumers and other users consider substitutable in terms of a common purpose, characteristics, and prices, and the relevant geographic market as the territory in which participants take part in demand or supply and where there are the same or similar conditions of competition, which significantly differ from the conditions of competition in the neighboring territories (The Republic of Serbia, 2009, Article 6 \& Eropean Union, 1997, Par. 7 and 8). Thus, the relevant product market includes all the products that significantly limit a change in the price of the analyzed product, and the relevant geographic market includes 
all the firms which are so located that they can have a significant influence on the price established by the company that is the subject of the analysis (ABA, 2005, 54).

That the relevant market involves a group of products in a particular territory, where a hypothetical monopolist has the ability to profitably slightly but permanently raise the price of his products can also be included in the previous conceptual definition of the relevant market (Coate \& Simons, 2012, 673-674). As such, the concept of the relevant market is narrower than the general concept of the market, which includes the exchange of goods and services in all the territories regardless of the conditions of competition and the existence of the substitutability of products (Geroski, 1998, 681). The following figure shows what the concept of the relevant market looks like.

Figure 1 demonstrates that the most important elements affecting the boundaries of the relevant market are supply-side and demand-side substitutability and potential competitors rarely included in the analysis.

The relevant market is the key instance which the application of the rules of competition depends on (Labus, 2008, 49). When investigating cases of the distortion of competition, in the first step, it is necessary that the boundaries within which a distortion occurs should be determined and that an appropriate action against these activities should be taken (Xianlin, 2008, 541). However, most researchers neglect the importance of defining the boundaries of the market for at least two reasons. First, because what happens in the market is always more interesting than its boundaries are, and second, defining the relevant market boundaries contains a large dose of subjectivity and for the majority of authors, it is not the field worthy of being analyzed (Geroski, 1998, 678). We will do our best to disregard these barriers and access the research that is of paramount importance to the protection of competition.

\section{Supply-side substitution}

Implies fast and inexpensive change in production without any additional risk in the event of a slight but permanent increase in price of the product

\section{The most effective short-term boundary to discipline sellers}

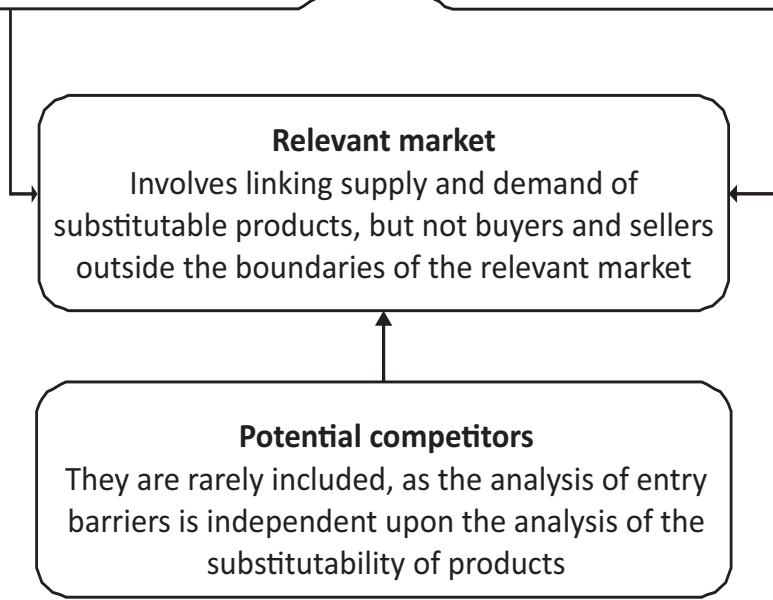

Figure 1 The concept of the relevant market 


\section{RESEARCH METHODOLOGY AND DATA COLLECTION}

Defining the boundaries of the relevant market in the production and geographic terms is predominantly based on the use of economic tests. The paper presents the market boundaries definition on the example of Serbian edible oil. An appropriate algorithm is used in defining the boundaries (Figure 2), where the emphasis is on the part of the algorithm which refers to the use of economic tests and the inclusion of the specifics of the analyzed markets.

Although the assertion that there is no commonly accepted approach, or test, to define the boundaries of the relevant market is still valid (Kaplow, 2012, 951), we have opted for the two commonly used tests, which are applicable to the data at our disposal. These are: the Correlation Price Test and the Goods Physical Movement Test (the Elzinga-Hogarty Test). The first test will be applied so as to define the relevant product market boundaries, and the other one so as to define the relevant geographic market boundaries. In economic theory, there are other tests used for defining the boundaries of the relevant market. The most common classification of tests is the one to those based on data about prices and those based on data about the movement of products (Slade, 1986, 293). The Hypothetical Monopolist Test (SSNIP) stands out among the techniques and belongs to the group of techniques based on the price movement; however, the available data did not allow it to be used.

\section{Price Correlation Test}

The Price Correlation Test shows how data about the prices of different products change over time. Some proponents of this test, such as G. J. Stigler and R. A. Sherwin (Stigler \& Sherwin, 1985, 555), believe that its source lies in the classic Marchallian understanding of the market, which says that a market is an area where product prices seek uniformity, and possible discrepancies are related to the amount of transportation and transaction costs (Geroski 1998, 679). The idea of the test is that the prices of products belonging to the same market tend to move in the same direction and with the same intensity (Motta, 2008, 107). If the prices of all potential substitutes are moving with the same intensity in the same direction,

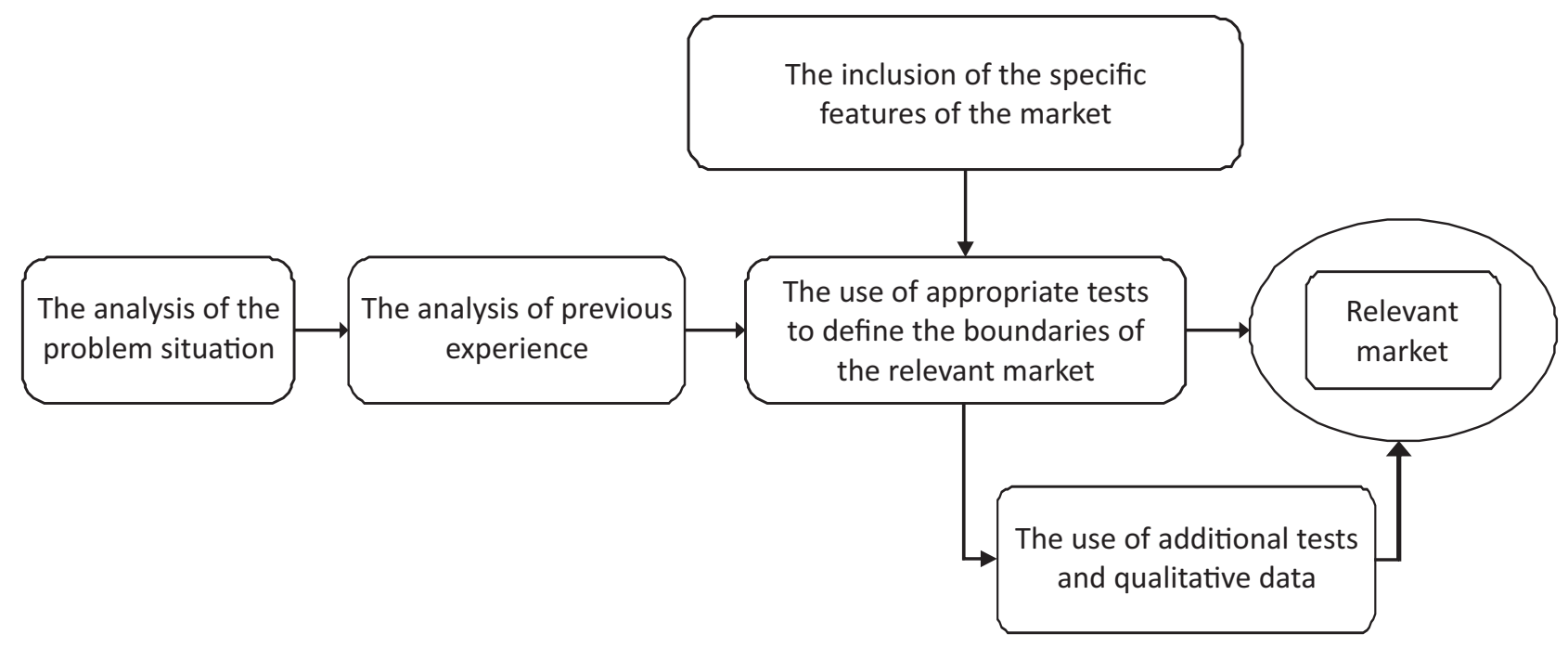

Figure 2 The algorithm of the definition of the relevant market boundaries 
then these products can be said to most likely belong to a single relevant product market. The same applies to the relevant geographic market, if the product prices of the companies stationed at different locations are analyzed (Massey, 2000, 315). The Price Correlation Test is very useful for testing the local as well as a wider relevant geographic markets (Cartwirght, Kamerschen, \& Huang, 1989, 79).

Correlation itself is a statistical technique examining whether there is a quantitative agreement between the two phenomena and if so, to what extent, where it does not matter which phenomenon is dependent and which one is independent. The correlation coefficient (Pearson's coefficient) can be determined using the following formula:

$$
r=\frac{n \sum x y-\sum x \sum y}{\sqrt{n \sum x^{2}-\left(\sum x\right)^{2} \sqrt{n \sum y^{2}-\left(\sum y\right)^{2}}}}
$$

where $\mathrm{n}$ is the number of the data pairs, and $\mathrm{x}$ and $\mathrm{y}$ are the variables whose correlation is being tested. The value of the coefficient obtained in this way can range from -1 to +1 , where -1 is the perfect inverse correlation and +1 the perfect direct correlation between the two phenomena, in this case the prices (Vuković, 2013, 201). The economic analysis of anti-monopoly cases takes +0.8 as the reference value, so if the value of the coefficient is below +0.8 , it means that such products do not belong to the same market, while any value above +0.8 means that there is a high probability that the analyzed products do belong to the same relevant market. However, the value above +0.8 does not automatically mean that the products are a part of a single market, but rather that it is necessary that additional analyses be carried out to confirm that (ABA, 2005, 62-63).

Anti-monopoly authorities in developed countries often use the price correlation test in the analysis of anti-competitive behavior, and a representative example is the case of the merging of the Nestle and Perrier corporations in the French market, where correlation between the price movement of bottled non-carbonated drinking water and non-carbonated juices was investigated. The research, which had been conducted during the five consecutive years, showed a low level of correlation in the price movements of these two products. Consequently, this fact enabled the definition of the relevant market for non-carbonated drinking water that does not contain other noncarbonated non-alcoholic beverages in itself (Motta, 2008, 108-109). The method based on movements in prices served a group of researchers to define the relevant electricity market in the case of the Nordic countries. Thus, Sweden, Finland, part of Denmark, and part of Norway belonged to one relevant market for the wholesale of electricity, while the second part of Norway and part of Denmark constituted a separate relevant market (Juselius \& Stenbacka, 2011, 186-188).

\section{The Product Movement Test - "Elzinga-Hogarty" Test}

In addition to the techniques based on the data about the price movement, the techniques based on the movement of products are also used in the antimonopoly policy. They are mainly used to determine the territorial boundaries of the market. One of the most important and the most commonly used technique as well is the Elzinga- Hogarty Test, which was created in the works of the authors after whom it was named in the 1970s. This test defines the relevant geographic market through data about the movement of products and is called the Product Movement Test. Its application eliminates the disadvantages of the tests based on data about the price movements (Elzinga \& Hogarty, 1973, 50).

The Elzinga-Hogarty Test determines the geographic boundaries of the market based on the percentage of the total spending accounting for the goods produced in the region and the percentage of the total production consumed in the region where it is produced. If both percentages are high, it indicates that the analyzed geographic area can be considered to be a single relevant market (Massey, 2000, 315). Otherwise, if the percentages are low, it means that the analyzed geographic area can be considered as part of a wider market. K. Elzinga and T. Hogarty recommended that the limit value of indicators should range from 0.75 to 0.9 (Stigler \& Sherwin, 1985, 580). This means that a market can be considered as single if part of spending which accounts for domestic production and part of the 
production placed in the domestic consumption range between $75 \%$ and $90 \%$. This logic can be applied in the opposite way, by the amount of goods that enter and leave a region, so that the region is a single market if a small part of the local consumption accounts for the products originating from other regions and if a small part of the local production crosses the borders of the region (Motta, 2008, 114). In accordance with the logic, the LIFO (Little In From Outside) and LOFI (Little Out From Inside) tests are used to assess whether a market is single. The LIFO test can be explained as a situation in which only a small percentage of spending in the region is "imported" from another region (Figure 3) (Elzinga \& Hogarty, 1973, 54).

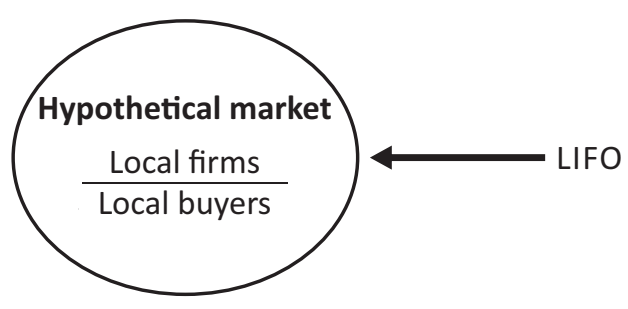

Figure 3 LIFO analysis

Source: Elzinga \& Hogarty, 1973, 54

The LOFI test can be explained as a situation in which only a small percentage of the local production is "exported" to another region (Figure 4) (Elzinga \& Hogarty, 1973, 58).

In case that the percentage of the LIFO and LOFI tests is less than $10 \%(0.1)$, a geographic area can be considered to be a "strong" relevant market; if it is higher than 10\% (0.1) but no higher than 25\% (0.25), it is a "weak" relevant market. Any value above $25 \%$ $(0.25)$ means that the geographic region is not a single relevant market, but rather a part of a wider market. (DOJ)

The aforementioned tests for determining the boundaries of the market are applied to the data obtained from the following sources: the National

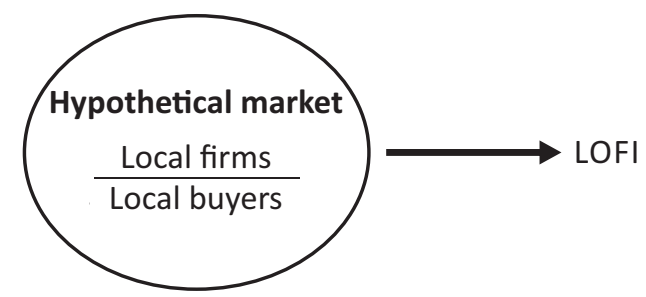

Figure 4 LOFI test

Source: Elzinga \& Hogarty, 1973, 58

Bureau of Statistics of the Republic of Serbia (the Statistical Yearbooks from 1994 to 2012), the Internet site of the European Bank for Reconstruction and Development (EBRD), the Internet portal of The Observatory of Economic Complexity (atlas.media.mit. edu), and the Internet portal of Index Mundi (www. indexmundi.com). The data of the National Bureau of Statistics were used for defining the boundaries of the relevant product market based on the data about the average annual retail prices of the analyzed product and its closest substitute. The data obtained from the website of the European Bank for Reconstruction and Development (EBRD) were used to reduce the current prices to the prices in 1994 in order to eliminate the effects of the inflation. The Internet portal of The Observatory of Economic Complexity was used to collect the data about the value of imports and exports and as a complement to this source, the Internet portal Index Mundi was used. The time frame in which the tests were being applied was from 1994 to 2012 for the Correlation Price Test and from 2005 to 2011 for the Elzinga-Hogarty Test. The time frame was based on the consistency and comparability of the available data. The statistical analysis was performed in the Statistical Package for Social Sciences - SPSS.

\section{RESEARCH RESULTS AND DISCUSSION}

\section{Defining the boundaries of the relevant product market}

As noted above, defining the boundaries of the relevant product market involves the definition of a product or a 


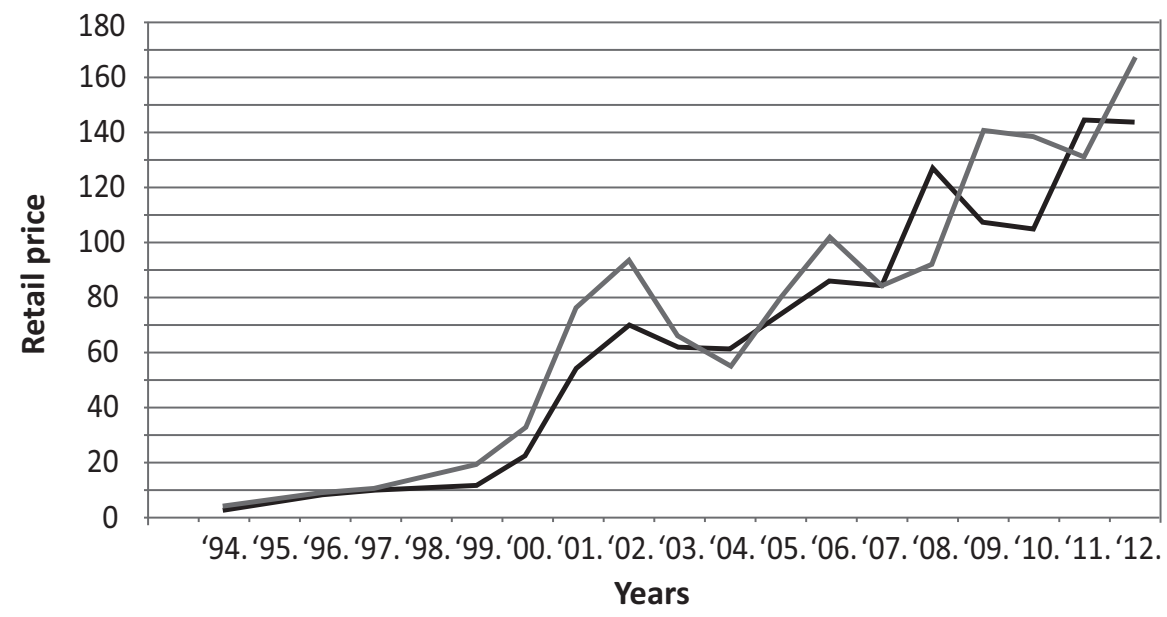

- Average retail price of edible oil of 1 liter - Average retail price of lard of $1 \mathrm{~kg}$

Figure 5 Movements in the current average retail prices of edible oil and lard in the period between 1994 and 2012

Source: Statistical Yearbooks of the Republic of Serbia between 1994 and 2012

group of products which make a single market in terms of their substitutability with conditions acceptable for consumers. Starting from the habits of consumers in Serbia, a logical substitute for edible oil is animal fat (mainly pork fat - hereinafter referred to as "lard") intended for human consumption. The substitutability of these products was tested through correlation in the price movement. The research was carried out on the example of the current average annual retail prices of edible oils and lard in the period between 1994 and 2012. Given the fact that these are annual average prices, there was no need to include any interval in the price movements between the analyzed products. The need for this would exist if the data were monthly or quarterly data. In Figure 5, the price movement of the analyzed products in the period between 1994 and 2012 can be seen.

Analyzing the data about the price movements of both products, their very similar trend can be noticed. This is confirmed by the following analysis. Table 1 shows the descriptive statistics data about the product price movement, whereas Figure 6 is a diagram of the dispersion of the data about the price movement.
With the dispersion diagram, the attitude about almost identical product price movements can be confirmed, as evidenced by the statistical analysis in Table 2 .

The statistical analysis (Table 2) leads us to a conclusion that there is a direct and very strong correlation between the movement of edible oil and lard, which is statistically significant, since $p<0.01$. The conclusion is that these two products can belong to the same relevant product market since the correlation coefficient is above the theoretical threshold of 0.8 . The confirmation of the thesis on belonging to a single market requires further testing because theoretically a high correlation coefficient is just the first indication of the existence of a single relevant market, but it does not necessarily mean that.

The conclusion on the high correlation of the price movement obtained on the basis of the data about the price movement given in this way is quite wrong because there is a significant common factor that impacts the price movement of the analyzed product and undermines the validity of the analysis - and 
Table 1 The descriptive statistics of the data about the movement in the current average retail prices of edible oil and lard in the period between 1994 and 2012

\begin{tabular}{|c|c|c|c|c|c|c|}
\hline & $z$ & 言 & 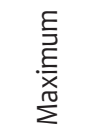 & $\stackrel{\frac{c}{\mathbb{N}}}{\sum}$ & 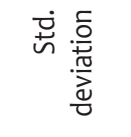 & 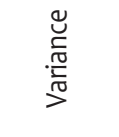 \\
\hline Edible oil & 19 & 1,93 & 143,94 & 62,26 & 48,40836 & 2343,370 \\
\hline Lard & 19 & 3,90 & 167,06 & 69,21 & 51,80404 & 2683,658 \\
\hline $\begin{array}{l}\text { Valid N } \\
\text { (listwise) }\end{array}$ & 19 & & & & & \\
\hline
\end{tabular}

Source: Author

that is inflation. The further research excludes the effect of inflation due to the objectivity of defining the boundaries of the market, and as a correction factor, we used the data about the consumer price movement at the disposal of the EBRD. The prices of the analyzed products were reduced to those in 1994, and based on these data, the testing of the boundaries of the relevant

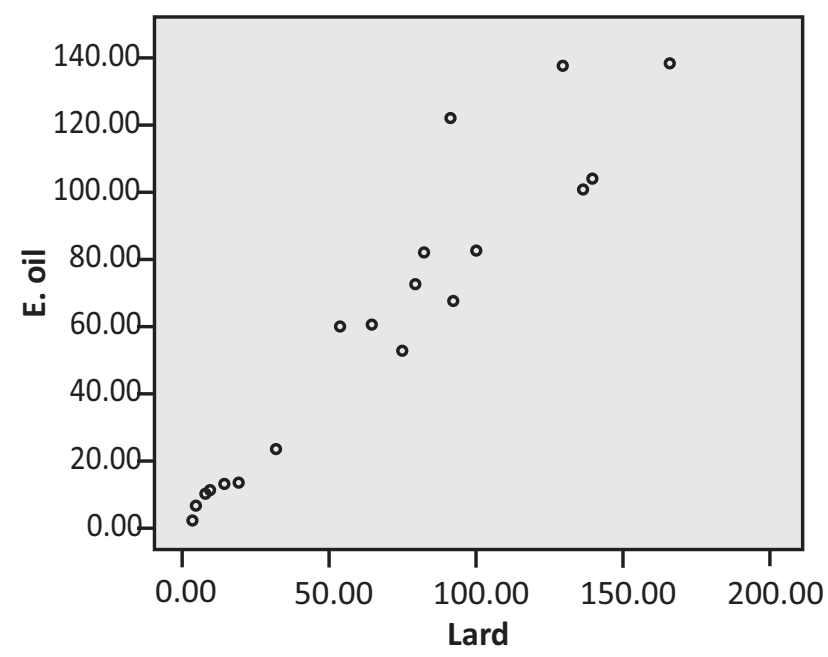

Figure 6 The diagram of the dispersion of the data about the movement in the current average retail prices of edible oil and lard in the period between 1994 and 2012
Table 2 The correlation coefficient of the movement in the current average retail prices of edible oil and lard in the period between 1994 and 2012

\begin{tabular}{ll|rr}
\hline & & E. oil & Lard \\
\hline E. oil & Pearson Correlation & 1 & $.949^{* *}$ \\
& Sig. (2-tailed) & & .000 \\
& $\mathrm{~N}$ & 19 & 19 \\
\hline Lard & Pearson Correlation & $.949^{* *}$ & 1 \\
& Sig. (2-tailed) & .000 & \\
& $\mathrm{~N}$ & 19 & 19 \\
\hline
\end{tabular}

**Correlation is significant at the 0.01 level (2-tailed)

Source: Author

product market was performed. Figure 7 makes it possible for us to conclude, as in the previous case, that the price movement of the analyzed products is similar, but to a smaller extent. This raises the question of whether this is really the case.

Tables 3 and 4 and Figure 8 point to the conclusion that the price movement of the analyzed products is not what it seemed to be at first. The dispersion diagram (Fig. 8) and the statistical analysis based on it (Table 4) are specifically indicative of this.

Based on the degree of correlation and the significance level given in Table 4, we can conclude that there is a moderate direct correlation not statistically significant between the price movement of edible oil and lard in the period between 1994 and 2012, expressed in the prices in 1994; therefore it can be concluded that the two products do not belong to the same relevant product market, but edible oil alone constitutes a relevant product market. In this way, we confirmed the research hypothesis $\mathrm{H} 1$.

\section{Relevant geographic market}

The relevant geographic market is a single territory with the similar conditions of competition.

The boundaries of the relevant market are determined using the LOFI and LIFO tests and the two simulations. The first one is based on the data obtained from the Statistical Yearbook of the Republic of Serbia and the 


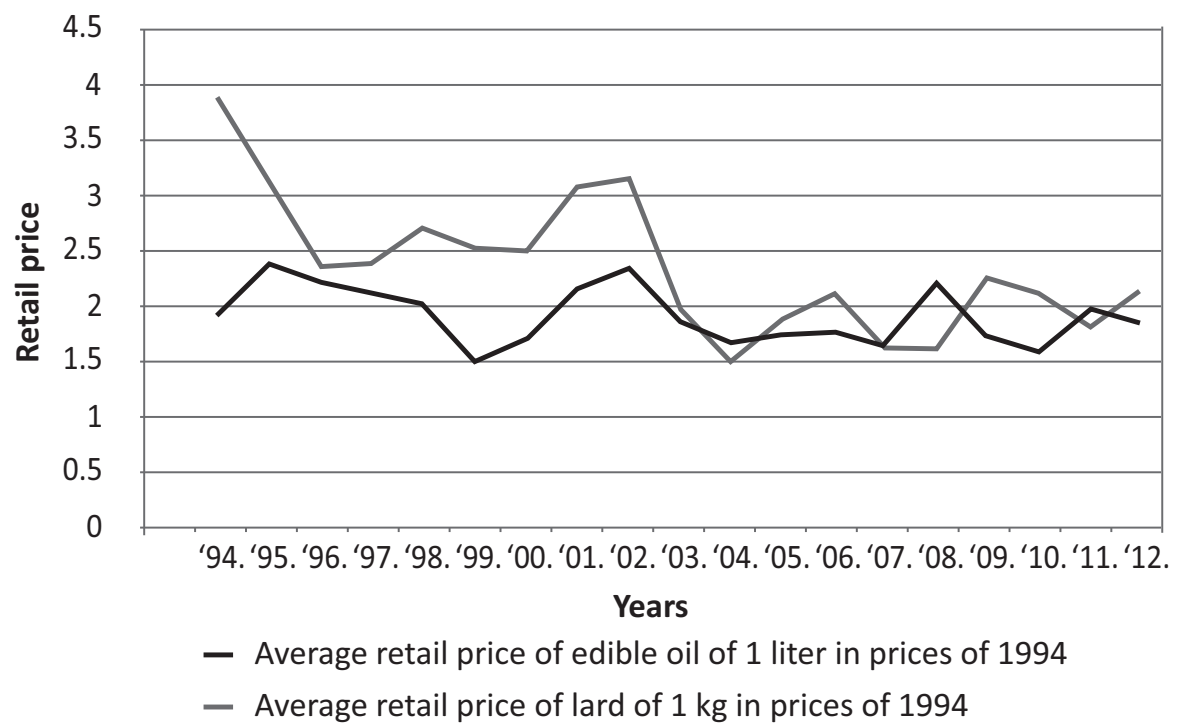

Figure 7 Movement in the retail prices of edible oil and lard in the period between 1994 and 2012, expressed in the prices in 1994

Source: Author

http://atlas.media.mit.edu site (The Observatory of Economic Complexity), whereas the other one is based on the data obtained from the http://www.indexmundi. $\mathrm{com} /$ site (Index Mundi). Assuming that the territory of Serbia, as a single relevant market, can be taken as the market of edible oil, using the available data about production, consumption, imports and exports, the hypothesis was tested.

Table 3 The descriptive statistics of the data about the movement in the retail prices of edible oil and lard in the period between 1994 and 2012, expressed in the prices in 1994

\begin{tabular}{|c|c|c|c|c|c|c|}
\hline & $z$ & 壱 & $\begin{array}{l}\frac{\xi}{\underline{\underline{E}}} \\
\frac{\underline{x}}{x} \\
\frac{\pi}{\Sigma}\end{array}$ & 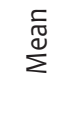 & 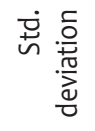 & 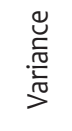 \\
\hline Edible oil & 19 & 1.53 & 2.39 & 1.94 & .26189 & .069 \\
\hline Lard & 19 & 1.51 & 3.90 & 2,37 & .61903 & .383 \\
\hline Valid N (listwise) & 19 & & & & & \\
\hline
\end{tabular}

Source: Author
Both simulations presented in Table 5 lead to similar results and conclusions that confirm their validity.

From the point of consumption, the value of the LIFO test indicates that Serbia is a single, generally "strong" relevant geographic market. From the point of

Table 4 The correlation coefficient of the movement in the retail prices of edible oil and lard in the period between 1994 and 2012, expressed in the prices in 1994

\begin{tabular}{ll|rr}
\hline & & E. oil & Lard \\
\hline E. oil & Pearson Correlation & 1 & .410 \\
& Sig. (2-tailed) & & .081 \\
& $\mathrm{~N}$ & 19 & 19 \\
\hline Lard & Pearson Correlation & .410 & 1 \\
& Sig. (2-tailed) & .081 & \\
& $\mathrm{~N}$ & 17 & 17 \\
\hline$* *$ Correlation is significant at the 0.01 level (2-tailed)
\end{tabular}

Source: Author 


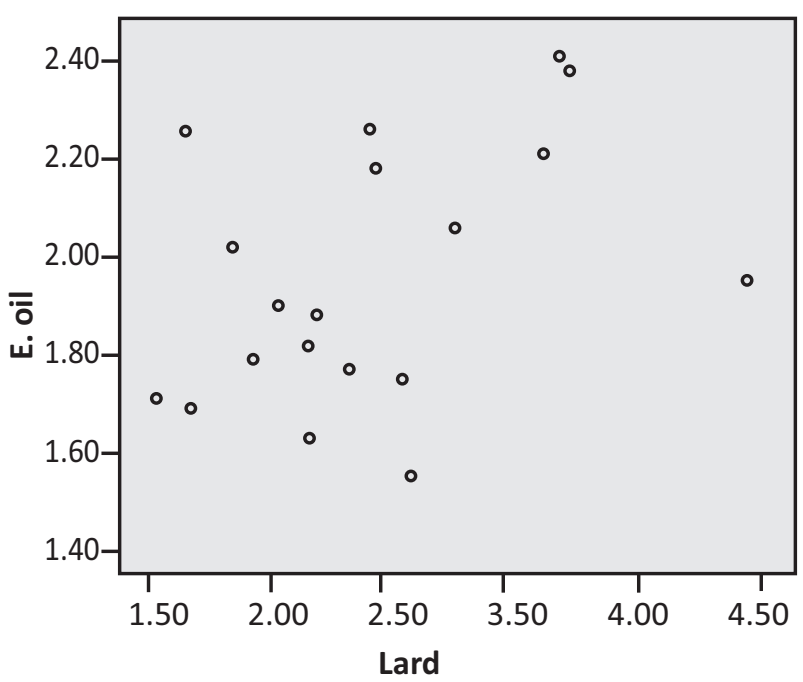

Figure 8 The diagram of the dispersion of the data about the movement in the retail prices of edible oil and lard in the period between 1994 and 2012, expressed in the prices in 1994

Source: Author

the LOFI test, the Serbian market is, in the observed period, generally part of a wider relevant market. However, the Competition Law, the fact that Serbia has not yet become part of the EU, and that - according to the volume of the production of edible oil - Serbia belongs to the group of the leading countries in the region diminish the importance of the LOFI test. It can be concluded that the territory of Serbia can be defined as the relevant geographic market in this research. This is especially corroborated by the fact that all the brands of edible oil produced in local firms are equally available at a similar price in the branched retail network. In this way, the research hypothesis H2 is confirmed.

Based on the foregoing, we can conclude that the relevant market for the examination of the market power of the economic entities producing edible oil is the edible oil market in the Republic of Serbia. In this way, the main research hypothesis is confirmed and the procedure for defining the relevant market boundaries is presented.
Table 5 LOFI and LIFO tests

\begin{tabular}{l|cc}
\hline Year & LOFI & LIFO \\
\hline \multicolumn{3}{|c}{ Simulation 1 } \\
\hline 2006 & 12.78 & 8.98 \\
2007 & 29.39 & 11.74 \\
2008 & 31.51 & 8.84 \\
2009 & 29.92 & 9.49 \\
2010 & 37.53 & 2.68 \\
\hline \multicolumn{3}{|c}{ Simulation 2 } \\
\hline 2006 & 31.68 & 15.09 \\
2007 & 35.65 & 6.00 \\
2008 & 35.56 & 5.88 \\
2009 & 57.65 & 4.21 \\
2010 & 45.29 & 2.11 \\
2011 & 50.00 & 2.27 \\
\hline
\end{tabular}

Source: Author

The boundaries of the relevant market so defined are of great importance for the implementation of the competition policy, because they allow the proper assessment of the market power of the economic entities operating in it by only including those entities that really affect the conditions of competition. In this manner, the market as a relatively wide term is reduced to a narrower, practical dimension. That is the reason why developed countries test the boundaries of the relevant market using the above-presented and similar techniques of the economic analysis. It follows that these techniques are very important for the practical conduct of the competition policy.

In the Serbian competition policy, the implementation of the aforementioned and similar techniques practically does not exist. Although the regulatory authorities declaratively advocate for a greater application of the economic analysis, it has not yet been implemented to the extent acceptable to the contemporary competition policy. Defining the boundaries of the market in Serbia is typically based on a descriptive assessment primarily based on the experience of a researcher, which can be a starting point for an analysis but not its ultimate achievement. 


\section{CONCLUSION}

According to the results, it can be concluded that the relevant market in its both dimensions includes edible oil on the entire territory of the Republic of Serbia. As such, it is a single market in which economic entities, whose market power can be estimated, operate. The determining of the boundaries of the market in which the power manifests is precisely a prerequisite for the determination of the market power. As a rule, companies with a large market share also have a great market power. However, in order for a market share to become a market power, companies need to possess the ability to profitably raise the price of their products.

The research has certain limitations, however, which certainly do not diminish its importance, but they need to be taken into account when making a new assessment of the market size. The limitations primarily concern the tests conducted.

As far as the Correlation Price Test is concerned, the problem that may arise in its implementation is related to the certain components of the price, such as transportation and transaction costs. These constituent elements of the price can greatly affect the level of correlation, but they are difficult to exclude. There is also the influence of the common factor, which is difficult to remove and may cause the prices of the products, which do not belong to the same market, to have the identical movement, so it is possible to reach a wrong conclusion that they belong to the same market. Such correlation is called the spurious correlation (Motta, 2008, 108) and the most frequent common factor affecting its creation is inflation. The research eliminated the influence of this factor. A very important limitation of the temporal (mis)matching of data is on the movement in the prices of the analyzed products. It happens that a change in the price of a product affects the price of another product with a certain time-lag and when this time-lag is included, we approach the value of correlation indicating that it is (or is not) about the products belonging to a single market (Slade, 1986, 293). The research did not include the time-lag, since these are annual data and their inclusion makes no sense.
On the other hand, the Product Movement Test is criticized because of the simplified understanding of the geographic market. The presence of the goods movement between regions is often not a sufficient condition to claim for a market to be part of a single market (Stigler \& Sherwin, 1985, 580). A significant movement of consumers between the territories is a possibility, which is the proof of the existence of the single market. What follows is that in defining the geographic boundaries of the market not only the mobility of goods but also the mobility of customers should additionally be studied as well. This is especially true in the service industries, where the test is applicable to a limited extent due to the characteristics of the goods (Elzinga \& Swisher, 2011, 143). There is also a problem with the joint involvement of the movement of finished goods, intermediate goods, and raw materials. It is common to only take the movement of finished products for convenience, rather than intermediate products and raw materials, although their movements may indicate the direction of the movement of the final bid. There is also a problem of the movement of the product because of different prices between territories. Care should be taken in the event that prices are different, since products are always exported to the region where the price is higher until prices have become equal. An analysis of the flow of goods at a time when prices are different can create a misleading picture of the connection between the two areas. Therefore, the analysis which is carried out when prices are equal and stable among regions is more precise. The problem of an asymmetric movement of goods between regions is also significant. It is the situation in which a region exports more of some products than it imports them. This problem existed in our research, but was removed with a greater emphasis on the importation of goods.

In addition to the limitations of the tests, the limitations of the research can also be mentioned. Along with the secondary data for the purpose of determining the market boundaries, the primary data obtained through surveys, where consumers give their opinions on the substitutability of the analyzed products, can be used as well. Also, they can declare on the degree of their attachment to domestic product brands. Such an analysis can be a complement to the previous tests. 
Furthermore, a series of collected data could be longer, which would ensure a greater validity of the research.

Despite all the limitations and problems, the tests are extremely useful and stand for a practical basis for defining the market boundaries. The paper should be understood in this light, as a pioneering venture in a higher application of the economic analysis in the area of the protection of competition. It is a trend in developed economies (the U.S. and the EU), where every decision aimed at sanctioning anticompetitive practice is based on the economic analysis - from defining the boundaries of the market to examining the consequences of such a behavior and measures for its elimination.

The application of the economic analysis is particularly important in the area of defining the market boundaries, because this ultimately determines the area in which conditions of competition are examined. The competition policy in the Republic of Serbia lacks exactly this economic analysis. The approach based on the factographic interpretation of the articles of law is insufficient. Every decision must be substantiated with the economic analysis. The introduction of legal acts and legislations by applying specific tests to determine the boundaries of the market could be a good approach to this.

Future research is likely to be related to the practical development of the issues concerning the relevant market and the definition of its borders, especially the removal of the limitations the analysis has encountered. Considerable attention will be focused on the assessment of the market power of corporations by applying appropriate indicators of concentration and inequality in the distribution of a market share.

\section{REFERENCES}

ABA (2005). Market Power Handbook. USA: American Bar Assocation, Sector of Antitrust Law.

ACPC (2009). Glosar termina koji se koriste u politici konkurencije Evropske unije - Antimonopolsko pravo i kontrola konkurencije. Beograd, Srbija: Tehnička pomoć Komisiji za zaštitu konkurencije.
Cartwirght, P. A., Kamerschen, D. R., \& Huang, M. Y (1989). Price Correlation and Granger Causality Tests for Market Definition. Review of Industrial Organization, 4(2), 79-98. doi: 10.1007/BF02284670

Coate, B. M., \& Simons, J. J (2012). In Defense of Market Definition. Antitrust Bulletin, 57(4), 667-717.

DOJ \& FTC (2010). Horizontal Merger Guidelines. USA: U.S. Departement of Justice and the Federal Trade Commission.

DOJ (n.d.). U.S. Department of Justice. Preuzeto 09.09.2012. sa http://www.justice.gov/atr/public/health_care204694/ chapter4.htm\#N37

EBRD (n.d.). Preuzeto 16.10.2012. sa http://www.ebrd.com/ pages/research/economics/data/macro.shtml\#macro

EBRD (n.d.) Preuzeto 30.03.2014. sa http://www.ebrd.com/ downloads/research/REP/rep-may-2013.pdf

EBRD (n.d.) Preuzeto 30.03.2014. sa http://www.ebrd.com/ downloads/research/REP/regional-economic-prospects1210. pdf

Elzinga, K., \& Hogarty, T (1973). The Problem of Geographic Market Definition in Antimerger Suits USA. Antitrust Bulletin, 18(1), 45-81.

Elzinga, K. G., \& Swisher, A. W (2011). Limits of the ElzingaHogarty Test in Hospital Mergers: The Evanston Case. International Journal of the Economics of Business, 18(1), 133-146. doi: 10.1080/13571516.2011.542963

European Union (1997). Commission Notice on the Definition of the Relevant Market for the Purposes of Community Competition Law. Official Journal of European Union.

Geroski, P. A (1998). Thinking creatively about markets. International Journal of Industrial Organization, 16(6), 677-695.

Index Mundi (n.d.). Preuzeto 16.10.2012. sa http://www. indexmundi.com

Juselius, M., \& Stenbacka, R (2011). The Relevant Market for Production. Scandinavian Jouranl of Economics, 113(1), 167-189. doi: 10.1111/j.1467-9442.2010.01640.x

Kaplow, L (2012). Market definition alchemy. Antitrust Bulletin, 57(4), 915-952.

Kostić, M (2007). Merenje koncentracije ponude grane. Ekonomski horizonti, 9(1-2), 89-108.

Kostić, M (2012). Značaj relevantnog tržišta za kvalitetnu procenu uslova konkurencije. U V. Leković (Red.), Institucionalne promene kao determinanta priorednog razvoja Srbije (249-260). Kragujevac: Ekonomski fakultet Univerziteta u Kragujevcu. 
Labus, M (2008). Uporedna analiza relevantnog tržišta koncept i primena. Ekonomika preduzeća, 56(1-2), 48-60.

Lopatka, E. J (2011). Market Definition? Review of Industrial Organization, 39(1-2), 69-93. doi: 10.1007/s11151-011-9302-z

Massey, P (2000). Market Definition and Market Power in Competition Analysis: Some Practical Issues. The Economic and Social Review, 31(4), 309-328.

Motta, M (2008). Competition Policy: Theory and Practice. Cambridge, UK: Cambridge University Press.

Republički zavod za statistiku Srbije (1995-2013). Statistički godišnjaci od 1994-2012. Beograd: Republički zavod za statistiku Srbije.

Republika Srbija (2009). Zakon o zaštiti konkurencije. Službeni glasnik Republike Srbije br. 51/09.

Slade, M. E (1986). Exogeneity Tests of Market Boundaries Applied to Petroleum Products. Journal of Industrial Economics, 34(3), 291-303.
Stadler, S. K (2009). Relevant Markets for Copyrighted Works Journal of Corporation Law. Journal of Corporation Law, 34(4), 1059-182.

Stigler, G. J., \& Sherwin, R. A (1985). The Extent of the Market. Journal of Law and Economics, 28(3), 555-585.

The Observatory of Economic Complexity (n.d.). Preuzeto 06.10.2012. sa http://atlas.media.mit.edu

Vuković, B. D (2013). Korelaciona analiza indikatora regionalne konkurentnosti: Primer Republike Srbije. Ekonomski horizonti, 15(3), 197-211. doi: 10.5937/ekonhor1303197V

Werden, G. J (1992). The History of Antitrust Market Delineation. Marquette Law Review, 76 (1), 123-215.

Xianlin, W (2008). On Defining Relevant Markets in Implementing the Antimonopoly Low of China. Frontiers of Law in China, 3 (4), 540-555. doi: 10.1007/s11463-008-0026-4

Received on $3^{\text {th }}$ March 2014, after revision, accepted for publication on $17^{\text {th }}$ April 2014.

Milan Kostic is an assistant professor in the area of expertise of General Economics and Economic Development at the Faculty of Economics in Kragujevac. He teaches Price Theory and Policy. He holds a PhD in the scientific field of Microeconomics - Industrial Organization at the Faculty of Economics, University of Kragujevac. He is currently engaged in a research in the field of the protection of competition, the relevant market boundaries definition, the degree of the market limitation, consumer ethnocentrism and privatization. 


\section{APPENDIX}

Table 1 The movement in the current average prices, the inflation of the adjusted prices of edible oils and lard in the period between 1994 and 2012 in Serbia

\begin{tabular}{|c|c|c|c|c|c|}
\hline Godina & $\begin{array}{l}\text { Prosečna cena na } \\
\text { malo jestivog ulja } \\
\text { od } 11\end{array}$ & $\begin{array}{l}\text { Prosečna cena na } \\
\text { malo sv. masti od } \\
1 \mathrm{~kg}\end{array}$ & Godišnja inflacija u \% & $\begin{array}{l}\text { Prosečna cena na } \\
\text { malo jestivog ulja od } \\
\text { 1l u cenama iz } 1994 \text {. }\end{array}$ & $\begin{array}{c}\text { Prosečna cena na } \\
\text { malo sv. masti od } 1 \\
\text { kg u cenama iz } 1994 .\end{array}$ \\
\hline 1994. & 1,93 & 3,90 & - & 1,93 & 3,90 \\
\hline 1995. & 4,26 & 5,61 & 78,60 & 2,39 & 3,14 \\
\hline 1996. & 7,78 & 8,25 & 94,30 & 2,24 & 2,38 \\
\hline 1997. & 8,85 & 9,84 & 18,30 & 2,16 & 2,40 \\
\hline 1998. & 10,89 & 14,50 & 30,00 & 2,04 & 2,72 \\
\hline 1999. & 11,53 & 19,10 & 41,10 & 1,53 & 2,54 \\
\hline 2000. & 22,12 & 32,18 & 70,00 & 1,73 & 2,51 \\
\hline 2001. & 53,65 & 75,63 & 91,80 & 2,19 & 3,08 \\
\hline 2002. & 69,23 & 93,21 & 19,50 & 2,36 & 3,18 \\
\hline 2003. & 61,65 & 65,39 & 11,70 & 1,88 & 2,00 \\
\hline 2004. & 61,14 & 54,50 & 10,10 & 1,69 & 1,51 \\
\hline 2005 & 74,30 & 80,06 & 16,50 & 1,77 & 1,90 \\
\hline 2006. & 85,13 & 101,13 & 12,70 & 1,80 & 2,13 \\
\hline 2007. & 84,36 & 83,15 & 6,50 & 1,67 & 1,65 \\
\hline 2008. & 127,03 & 92,32 & 12,40 & 2,24 & 1,63 \\
\hline 2009. & 107,14 & 140,18 & 8,10 & 1,75 & 2,29 \\
\hline 2010. & 104,65 & 138,31 & 5,70 & 1,61 & 2,13 \\
\hline 2011. & 143,94 & 130,69 & 11,10 & 2,00 & 1,82 \\
\hline 2012. & 143,34 & 167,06 & 7,30 & 1,86 & 2,16 \\
\hline
\end{tabular}

Source: The table has been made on the basis of the data obtained from the Statistical Yearbooks of the Republic of Serbia between 1994 and 2012; the http://www.ebrd.com/pages/research/economics/data/macro.shtml\#macrosite, downloaded on 16/10/2011, the http://www.ebrd.com/downloads/research/REP/rep-may-2013.pdf site, downloaded on 30/03/2014 and the http://www.ebrd.com/ downloads/research/REP/regional-economic-prospects1210.pdf site, downloaded on 30/03/2014 


\title{
TESTIRANJE GRANICA RELEVANTNOG TRŽIŠTA U POLITICI ZAŠTITE KONKURENCIJE
}

\author{
Milan Kostić* \\ Ekonomski fakultet Univerziteta u Kragujevcu
}

Pojam relevantnog tržišta je veoma značajan za politiku zaštite konkurencije. Od dimenzija relevantnog tržišta zavisi procena tržišne moći privrednih subjekata koji na njemu posluju. Relevantno tržište poseduje dve dimenzije: proizvodnu i geografsku, tako da postoji relevantno tržište proizvoda i relevantno geografsko tržište. Svrha rada je da na eksplicitan i sistematičan način prikaže moguće načine određivanja granica relevantnog tržišta primenom odgovarajućih testova, na primeru konkretnog tržišta u privredi Republike Srbije. U radu su primenjena dva značajna testa za određivanje granica tržišta: Test korelacije cena i Test fizičkog kretanja dobara (Elzinga-Hogarti test). Ovi testovi su izuzetno upotrebljivi u situacijama kada istraživači poseduju samo sekundarne podatke i žele na osnovu njih da odrede granice tržišta. Nedostaci testova, kojih, naravno, ima, ne umanjuju njihov značaj, tako da su oni veoma korisni i preporučljivi za određivanje opsega tržišta.

Ključne reči: relevantno tržište, politika zaštite konkurencije, Test korelacije cena, Elzinga-Hogarti test

\section{UVOD}

Definisanje granica relevantnog tržišta je neophodna pretpostavka određivanja tržišne moći korporacija, pa je shodno tome i prva faza $\mathrm{u}$ analizi uslova konkurencije (Xianlin, 2008, 541). Različito definisano relevantno tržište implicira različitu procenu tržišne moći korporacija, pa se tako dešava da ista firma $\mathrm{u}$ različitim postupcima pred antimonopolskim autoritetima ima različitu tržišnu moć (ABA, 2005, 5354). Ako su granice relevantnog tržišta usko definisane,

\footnotetext{
* Korespondencija: M.Kostić, Ekonomski fakultet Univerziteta u Kragujevcu, Đ. Pucara 3, 34000 Kragujevac, Srbija; e-mail:mkostic@kg.ac.rs
}

pojedinačne firme će verovatno uživati veće tržišno učešće, i posledično veću tržišnu moć, nego da je tržište šire definisano (Stadler, 2009, 1062). Upravo od definisanja granica relevantnog tržišta zavisi i procena njegove ograničenosti (Kostić, 2007, 105). Proizilazi da fenomen relevantnog tržišta na sistematski i sveobuhvatan način određuje okvir unutar kojeg se analiziraju uslovi konkurencije i primenjuju pravila zaštite konkurencije, pa se može slobodno reći da pripada antimonopolskoj dogmi, koja danas sve više dobija na značaju (ACPC, 2009, 83; Lopatka, 2011, 69).

Definisanje granica relevantnog tržišta ima dva aspekta: prvi je definisanje linija proizvoda, koje su međusobno zamenljive, i geografskih oblasti, na 
kojima se ta zamenljivost ostvaruje; i drugi, koji se odnosi na određivanje tržišnih učesnika, njihovog tržišnog učešća i stepena koncentracije tržišta koji iz toga proizilazi (DOJ \& FTC, 2010, 7).

Predmet ovog rada jeste testiranje granica relevantnog tržišta na primeru jednog sektora privrede Republike Srbije (RS). Na taj način nastojaćemo da pokažemo značaj ovog segmenta ekonomske analize za politiku zaštite konkurencije. Cilj rada je da pruži okvir u kome treba odrediti granice relevantnog tržišta primenom odgovarajućih ekonomskih testova. Polazeći od definisanog predmeta i cilja istraživanja pristupićemo testiranju istraživačkih hipoteza kako bi odredili granice relevantnog tržišta.

Osnovna istraživačka hipoteza glasi:

H0 : Tržište jestivog ulja se može tretirati kao zaokruženo relevantno tržište koje se prostire na teritoriji celokupne Republike Srbije.

Iz ove hipoteze proizilaze dve dopunske hipoteze i tiču se pojedinačnih dimenzija relevantnog tržišta:

H1 : Jestivo ulje samostalno konstituiše relevantno tržište proizvoda.

H2 : Relevantno geografsko tržište na kojem se prodaje jestivo ulje je teritorija Republike Srbije.

Shodno opredeljenom predmetu, cilju i naučnim hipotezama izvršeno je istraživanje na osnovu sekundarnih podataka koji su bili dostupni u statističkim publikacijama i bazama podataka relevantnih domaćih i inostranih institucija. Dobijeni podaci su korišćeni u skladu sa procedurama koje zahtevaju tehnike određivanja granica relevantnog tržišta, te su na taj način testirane istraživačke hipoteze.

Rad je tako koncipiran da u sebi sadrži pet celina. Pored uvoda, rad sadrži teorijsku osnovu pojma relevantnog tržišta, opis metodologije i načina prikupljanja podataka, rezultate istraživanja sa diskusijom, i zaključna razmatranja sa ograničenjima istraživanja i samog rada.

\section{TEORIJSKA OSNOVA}

Po pitanju određivanja pojma, pa samim tim i granica tržišta, stavovi ekonomista su se tokom vremena menjali, što se posebno komplikuje pojavom teorija ograničene i monopolističke konkurencije sredinom XX-og veka (Werden, 1992, 126). Tokom 70-ih i 80ih godina $X X-o g$ veka pojavljuju se prvi tekstovi o relevantnom tržištu i njegovim granicama. Tada ovaj pojam ulazi u ekonomsku literaturu vezujući se prevashodno za politiku zaštite konkurencije (Massey, 2000,313 ). Istovremeno, sa pojavom ovog pojma dolazi do intenzivne primene ekonomske analize u ovoj sferi državne regulative (Kostić, 2012, 250).

Relevantno tržište, kao prostor na kojem se sučeljava konkurencija, ima dve dimenzije - proizvodnu i geografsku, što praktično znači da ono mora biti definisano sa aspekta asortimana i sa aspekta prostora na kojem se taj asortiman prodaje. Iz ovoga sledi da relevantno tržište obuhvata relevantno tržište proizvoda i relevantno geografsko tržište (Labus, 2008, 52). Relevantno tržište proizvoda se pretežno definiše kao skup roba i usluga koje potrošači i drugi korisnici smatraju zamenljivim u pogledu uobičajene namene, karakteristika i cene, dok se relevantno geografsko tržište definiše kao teritorija na kojoj ekonomski subjekti učestvuju u ponudi ili tražnji i na kojoj postoje isti ili slični uslovi konkurencije, koji se značajno razlikuju od uslova konkurencije na susednim teritorijama (Republika Srbija, 2009, član 6; European Union, 1997, par. 7 and 8). Tako, relevantno tržište proizvoda uključuje sve proizvode koji bitno ograničavaju promenu cene analiziranog proizvoda, dok relevantno geografsko tržište uključuje sve firme koje su locirane tako da mogu bitno uticati na cenu koju formira kompanija koja je predmet analize (ABA, 2005, 54).

Prethodnom pojmovnom određenju relevantnog tržišta može se priključiti i sledeće: da relevantno tržište podrazumeva grupu proizvoda na određenoj teritoriji gde hipotetički monopolista ima mogućnost da profitabilno, malo, ali trajno podigne cenu svojih proizvoda (Coate \& Simons, 2012, 673-674). Kao takav, fenomen relevantnog tržišta je uži od opšteg koncepta tržišta, koji obuhvata razmenu roba i usluga na svim teritorijama nezavisno od uslova konkurencije i postojanja zamenljivosti proizvoda (Geroski, 1998, 681). Slika 1 prikazuje koncept relevantnog tržišta. Sa Slike 1 može se videti da su najznačajniji elementi koji utiču na granice relevantnog tržišta zamenljivost na strani ponude i tražnje i potencijalni konkurenti, koji se po pravilu retko uključuju u analizu.

Relevantno tržište je ključna instanca od koje zavisi primena pravila zaštite konkurencije (Labus, 2008, 


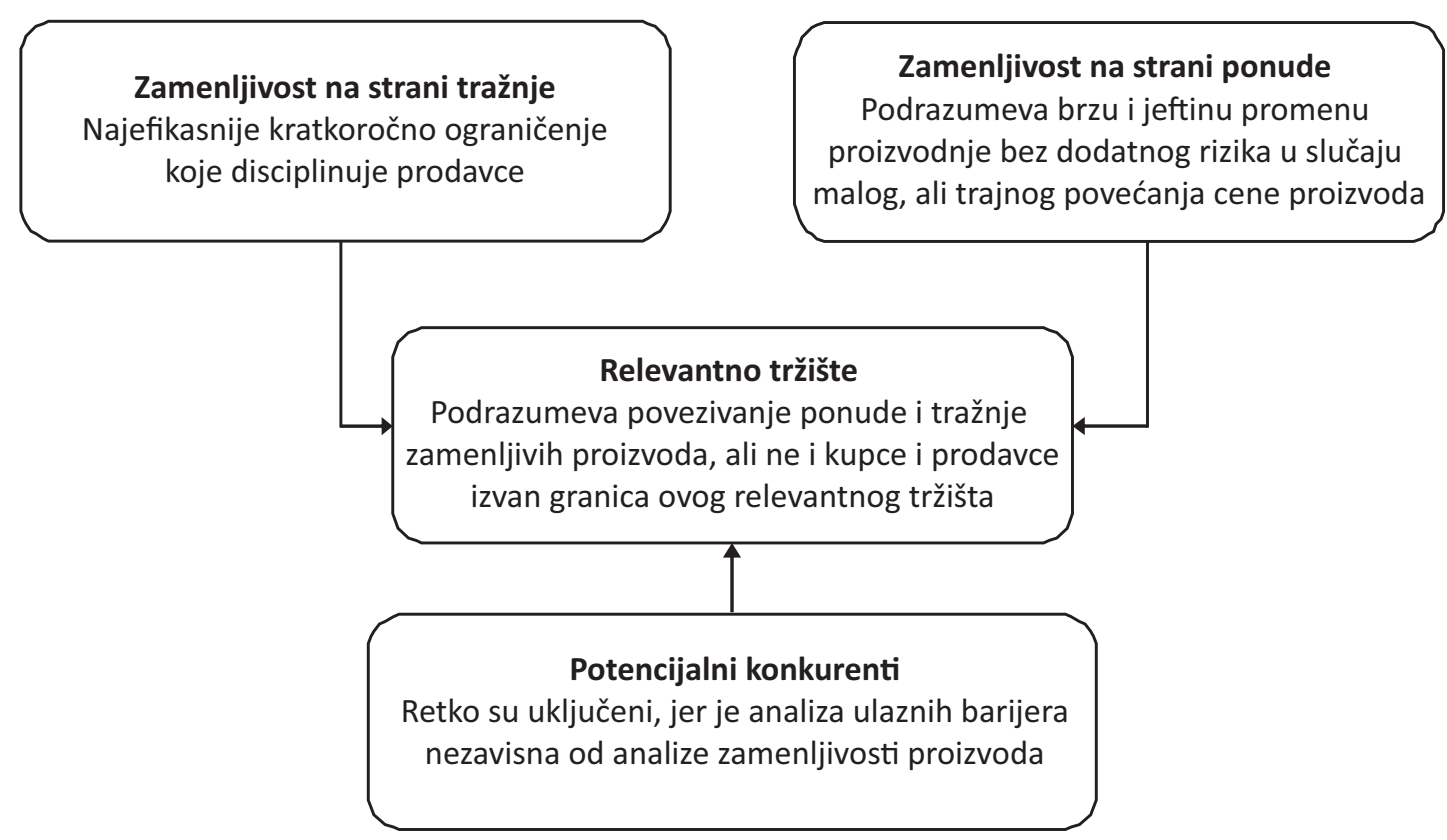

Slika 1 Koncept relevantnog tržišta

Izvor: Labus, 2008, 53

49). Prilikom istraživanja slučajeva narušavanja konkurencije neophodno je u prvom koraku odrediti granice u okviru kojih se to narušavanje dešava, a zatim preduzeti odgovarajuće mere protiv tih aktivnosti (Xianlin, 2008, 541). Međutim, većina istraživača zanemaruje značaj definisanja granica tržišta iz najmanje dva razloga: prvi, jer je uvek interesantnije ono što se dešava na tržištu, a ne njegove granice, $i$ drugi, jer definisanje granica relevantnog tržišta u sebi sadrži veliku dozu subjektivnosti, pa za većinu autora nije polje dostojno analize (Geroski, 1998, 678). Mi ćemo se potruditi da ove prepreke zanemarimo i pristupimo istraživanju koje je od ogromnog značaja za polje zaštite konkurencije.

\section{METODOLOGIJA ISTRAŽIVANJA I IZVORI PODATAKA}

Određivanje granica relevantnog tržišta, $u$ proizvodnom i geografskom smislu, bazira se dominantno na primeni ekonomskih testova. U radu će biti prikazano određivanje granica tržišta na primeru jestivog ulja Republike Srbije, gde se za definisanje granica koristi odgovarajući algoritam (Slika 2), pri čemu je naglasak na delu algoritma koji se odnosi na primenu ekonomskih testova i uključivanje specifičnosti analiziranog tržišta.

Iako još uvek važi tvrdnja da ne postoji opšteprihvaćen način, odnosno, test, za definisanje granica relevantnog tržišta (Kaplow, 2012, 951), mi smo se opredelili za dva često korišćena testa, koja su primenljiva na podacima sa kojima smo raspolagali. To su: Test korelacije cena i Test fizičkog kretanja proizvoda (ElzingaHogarti test). Prvi test će biti primenjen za definisanje granica relevantnog tržišta proizvoda, a drugi za definisanje granica relevantnog geografskog tržišta. U ekonomskoj teoriji postoje i drugi testovi koje se koriste za utvrđivanje granica relevantnog tržišta. Najčešća podela testova je na one koji se zasnivaju na podacima o cenama i one koji su bazirani na podacima o kretanju proizvoda (Slade, 1986, 293). Među tehnikama se izdvaja test hipotetičkog monopoliste (SSNIP test) koji pripada grupi tehnika zasnovanih na kretanju cena. 


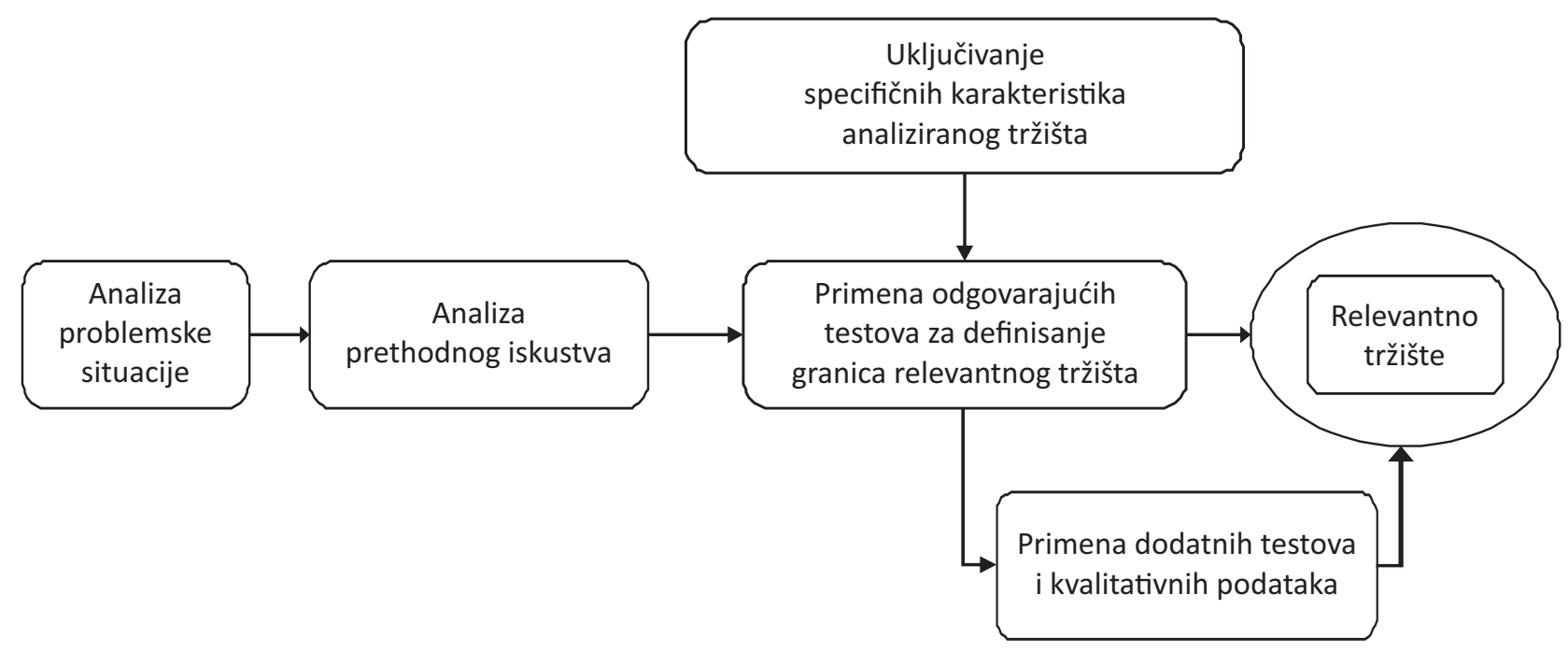

Slika 2 Algoritam definisanja granica relevantnog tržišta

Izvor: Autor

Međutim, u analiziranom slučaju, raspoloživi podaci nisu dozvolili njegovo korišćenje.

\section{Test korelacije cena}

Test korelacije cena pokazuje kako se podaci o cenama različitih proizvoda menjaju tokom vremena. Neki zagovornici ovog testa, kao što su G. J. Stigler i R. A. Shervin (Stigler \& Sherwin, 1985, 555), smatraju da njegovo izvorište leži u klasičnom maršalijanskom shvatanju tržišta, koje kaže da je tržište prostor na kojem cene proizvoda teže uniformnosti, a moguća odstupanja su vezana za visinu transportnih i transakcionih troškova (Geroski, 1998, 679). Ideja testa je da cene proizvoda koji pripadaju istom tržištu teže da se pomeraju $u$ istom pravcu, $i$ to istim intenzitetom (Motta, 2008, 107). Ako se cene svih potencijalnih supstituta kreću istim intenzitetom $\mathrm{u}$ istom pravcu, onda se za te proizvode može reći da vrlo verovatno pripadaju jedinstvenom relevantnom tržištu proizvoda. Isto važi i za relevantno geografsko tržište ako se analiziraju cene proizvoda preduzeća stacioniranih na različitim lokacijama (Massey, 2000, 315). Test korelacije cena je veoma koristan za testiranje lokalnih, ali i širih geografskih relevantnih tržišta (Cartwirght, Kamerschen, \& Huang, 1989, 79).

Sama korelacija predstavlja statističku tehniku koja ispituje da li između dve pojave postoji kvantitativno slaganje i, ako postoji, u kom je stepenu, pri čemu nije bitno koja pojava je zavisna, a koja nezavisna. Koeficijent korelacije (Pirsonov koeficijent) se može odrediti preko sledeće formule:

$$
r=\frac{n \sum x y-\sum x \sum y}{\sqrt{n \sum x^{2}-\left(\sum x\right)^{2} \sqrt{n \sum y^{2}-\left(\sum y\right)^{2}}}}
$$

gde je $\mathrm{n}$ broj parova podataka, a $\mathrm{x}$ i y promenljive čija se korelacija ispituje. Vrednost ovako dobijenog koeficijenta može biti od -1 do +1 , pri čemu je -1 savršena inverzna korelacija, a +1 savršena direktna korelaciona veza između kretanja dve pojave, $u$ ovom slučaju cena (Vuković, 2013, 201). Ekonomska analiza antimonopolskih slučajeva uzima $+0,8$ kao graničnu vrednost, pa tako ako je vrednost koeficijenta ispod $+0,8$ govori se o tome da proizvodi ne pripadaju istom tržištu, dok svaka vrednost iznad $+0,8$ znači da postoji velika verovatnoća da analizirani proizvodi pripadaju 
istom relevantnom tržištu. Međutim, vrednost iznad $+0,8$ ne znači automatski da su proizvodi deo jedinstvenog tržišta, već da je potrebno uraditi dodatne analize koje to potvrđuju (ABA, 2005, 62-63).

Antimonopolski autoriteti razvijenih zemalja često $\mathrm{u}$ analizi nekonkurentnog ponašanja koriste test korelacije cena, a reprezentativni primer je slučaj povezivanja korporacija Nestle i Perrier na francuskom tržištu, kada je ispitivana veza u kretanju cena flaširane negazirane vode za piće i negaziranih sokova. Istraživanje, koje je obuhvatalo pet uzastopnih godina pokazalo je nizak nivo korelacije $\mathrm{u}$ kretanju cena ova dva proizvoda. Posledično, ova činjenica je omogućila definisanje relevantnog tržišta negazirane vode za piće, koje u sebi ne sadrži druga negazirana bezalkoholna pića (Motta, 2008, 108-109). Metoda zasnovana na kretanju cena poslužila je i grupi istraživača za definisanje relevantnog tržišta električne energije u slučaju nordijskih zemalja. Tako su Švedska, Finska, deo Danske i deo Norveške pripali jednom relevantnom tržištu veleprodaje električne energije, dok su drugi deo Norveške i deo Danske činili zasebno relevantno tržište (Juselius \& Stenbacka, 2011, 186-188).

\section{Test fizičkog kretanja proizvoda - „Elzinga- Hogarti" test}

Pored tehnika zasnovanih na podacima o kretanju cena, $\mathrm{u}$ antimonopolskoj politici koriste se i tehnike zasnovane na fizičkom kretanju proizvoda. One se uglavnom koriste za određivanje teritorijalnih granica tržišta. Jedna od najznačajnijih, a ujedno i najčešće korišćena tehnika je Elzinga-Hogarti test (ElzingaHogarty test), koji je nastao tokom 70-ih godina XXog veka u radovima autora po kojima je i dobio ime. Ovaj test definiše relevantno geografsko tržište preko podataka o fizičkom kretanju proizvoda, pa se naziva i Test fizičkog kretanja proizvoda. Njegovom primenom eliminišu se nedostaci testova baziranih na podacima o kretanju cena (Elzinga \& Hogarty, 1973, 50).

Elzinga-Hogarti test određuje geografske granice tržišta preko procenta ukupne potrošnje koji otpada na dobra proizvedena $u$ regionu i procenta ukupne proizvodnje koji se potroši $u$ regionu gde se i proizvede. Ako su oba procenta visoka, to govori o tome da se analizirana geografska oblast može smatrati zaokruženim relevantnim tržištem (Massey, 2000, 315). U suprotnom, ako su procenti mali, to znači da se analizirana geografska oblast može smatrati delom šireg tržišta. K. Elzinga i T. Hogarti su preporučili da se kao granična vrednost prihvati visina pokazatelja od 0,75 do 0,9 (Stigler \& Sherwin, 1985, 580). To znači da se tržište može smatrati zaokruženom celinom ako deo potrošnje koji otpada na domaću proizvodnju i deo proizvodnje koji se plasira u domaću potrošnju iznosi između 75 i 90\%. Ovakva logika se može primeniti na količinu dobara koja uđe i izađe iz nekog regiona. Region će predstavljati zaokruženo tržište ako mali deo lokalne potrošnje otpada na proizvode poreklom iz drugih regiona i ako mali deo lokalne proizvodnje odlazi van regiona (Motta, 2008, 114). U skladu sa ovom logikom za procenu zaokruženosti tržišta koriste se LIFO (Little In From Outside) i LOFI (Little Out From Inside) test. LIFO test se može objasniti kao situacija u kojoj se samo mali procenat potrošnje regiona "uvozi" iz drugog regiona (Slika 3) (Elzinga \& Hogarty, 1973, 54).

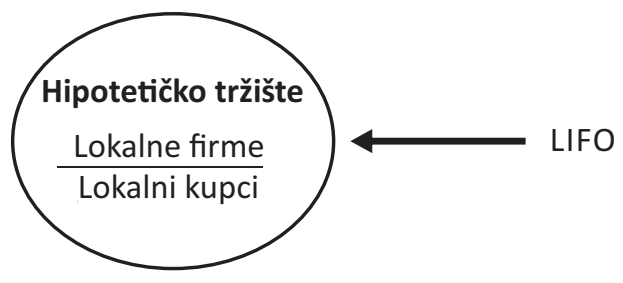

Slika 3 LIFO analiza

Izvor: Elzinga \& Hogarty, 1973, 54

LOFI test se može objasniti kao situacija u kojoj se samo mali procenat lokalne proizvodnje „izvozi“ na tržište drugog regiona (Slika 4) (Elzinga \& Hogarty, 1973, 58)

U slučaju da je procenat LIFO i LOFI testa manji od $10 \%(0,1)$, geografska oblast se može smatrati ,jakim" relevantnim tržištem, a ako je preko $10 \%(0,1)$, a ne veći od 25\% $(0,25)$, „slabim“ relevantnim tržištem. Vrednost iznad 25\% $(0,25)$ znači da geografski region ne čini 
samostalno relevantno tržište, već je deo šireg tržišta (DOJ).

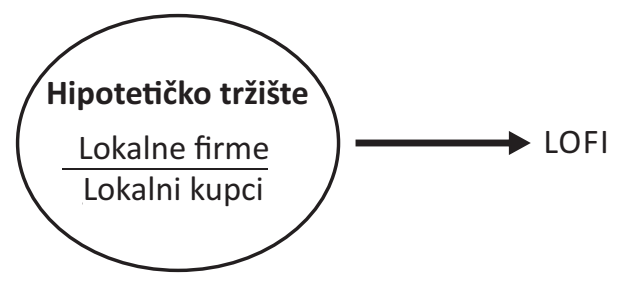

Slika 4 LOFI analiza

Izvor: Elzinga \& Hogarty, 1973, 58

Pomenuti testovi za određivanje granica tržišta primenjeni su na podacima dobijenim iz sledećih izvora: Republički zavod za statistiku Republike Srbije (Statistički godišnjaci od 1994. do 2012. godine), Internet sajt Evropske banke za obnovu i razvoj (EBRD), Internet portal The Observatory of Economic Complexity (atlas.media.mit.edu) i Internet portal Index Mundi (www.indexmundi.com). Podaci Republičkog zavoda za statistiku poslužili su za definisanje granica relevantnog tržišta proizvoda, i to na bazi podataka o prosečnim godišnjim cenama na malo analiziranog proizvoda i njegovog najbližeg supstituta. Podaci dobijeni sa sajta Evropske banke za obnovu i razvoj (EBRD) korišćeni su za svođenje tekućih cena na cene iz 1994. godine, kako bi se eliminisao uticaj inflacije. Internet portal The Observatory of Economic Complexity je korišćen da se prikupe podaci o vrednosti uvoza i izvoza, a kao dopuna ovom izvoru korišćen je i Internet portal Index Mundi. Vremenski okvir u kome su primenjeni testovi je 1994-2012. godina za Test korelacije cena, i 20052011. godina za Elzinga-Hogarti test. Uzeti vremenski okvir je zasnovan na konzistentnosti i uporedivosti raspoloživih podataka. Statistička obrada podataka je sprovedena u programu Statistički paket za društvene nauke (Statistical Package for Social Sciences - SPSS).
REZULTATI ISTRAŽIVANJA I DISKUSIJA

\section{Relevantno tržište proizvoda}

Kao što je već rečeno, definisanje granica relevantnog tržišta proizvoda podrazumeva određivanje proizvoda ili grupe proizvoda koji čine zaokruženo tržište $u$ smislu njihove zamenljivosti uz prihvatljive uslove za potrošače. Polazeći od navika potrošača u Republici Srbiji (RS), kao logični supstitut za jestivo ulje izdvaja se životinjska mast (pretežno svinjska) namenjena ishrani. Zamenljivost ovih proizvoda testirana je preko korelacije $\mathrm{u}$ kretanju njihovih cena. Istraživanje je izvršeno na primeru tekućih prosečnih godišnjih cena na malo jestivog ulja i svinjske masti u periodu od 1994. do 2012. godine. S obzirom na to da se radi o godišnjim prosečnim cenama, nije bilo potrebe za uključivanjem bilo kakvog vremenskog razmaka u kretanju cena između analiziranih proizvoda. Potreba za ovim bi postojala da se raspolagalo mesečnim ili kvartalnim podacima. Na Slici 5 može se videti kretanje cena analiziranih proizvoda $u$ periodu od 1994. do 2012. godine.

Analizom podataka o kretanju cena oba proizvoda može se uočiti njihovo veoma slično kretanje. To potvrđuje i sledeća analiza. Tabela 1, pokazuje podatke deskriptivne statistike o kretanju cena proizvoda, dok Slika 6 predstavlja dijagram rasturanja podataka o kretanju cena. Sa dijagrama rasturanja može se potvrditi stav o skoro identičnom kretanju cena proizvoda, što pokazuje i statistička analiza data $\mathrm{u}$ Tabeli 2. Na osnovu statističke analize (Tabela 2) može se zaključiti da između kretanja cena jestivog ulja i svinjske masti postoji direktna veoma jaka korelaciona veza, koja je statistički značajna, jer je $p<0,01$. Sledi zaključak da ova dva proizvoda mogu pripadati istom relevantnom tržištu proizvoda, s obzirom da je koeficijent korelacije iznad teorijskog praga od 0,8 . Potvrda teze o pripadnosti jedinstvenom tržištu zahteva dodatno testiranje, jer teorija kaže da je visok koeficijent korelacije samo prvi pokazatelj postojanja jedinstvenog relevantnog tržišta, ali ne i dovoljan.

Zaključak o visokoj korelaciji u kretanju cena koji je dobijen na osnovu ovako datih podataka o kretanju 


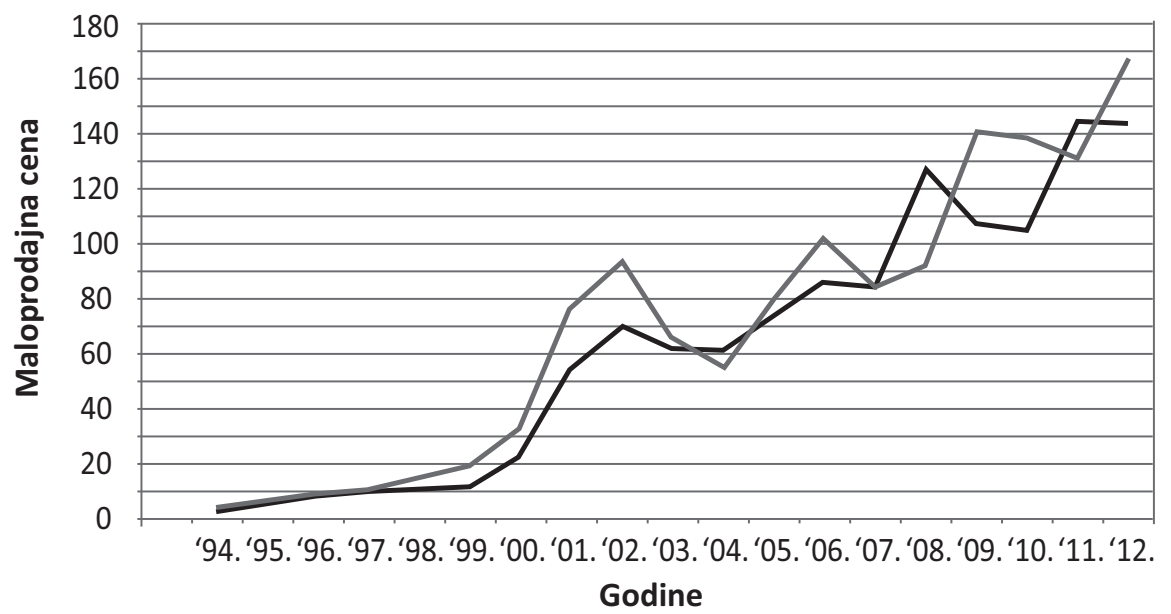

- Prosečna cena na malo jestivog ulja od $1 \mathrm{~L}$ - Prosečna cena na malo s. masti od $1 \mathrm{~kg}$

Slika 5 Kretanje prosečnih tekućih cena na malo jestivog ulja i svinjske masti u periodu 1994-2012.

Izvor: Statistički godišnjaci R. Srbije 1994-2012.

cena je pod znakom pitanja, jer. na kretanje analiziranih proizvoda utiče jedan značajan zajednički faktor koji narušava valjanost analize, a to je inflacija. U nastavku istraživanja je, zbog objektivnosti određivanja granica tržišta, isključeno delovanje inflacije, a kao korektivni faktor korišćeni su podaci o kretanju potrošačkih cena sa kojima raspolaže EBRD.

Tabela 1 Deskriptivna statistika podataka o kretanju prosečnih tekućih cena na malo jestivog ulja i svinjske masti u periodu 1994-2012.

\begin{tabular}{|c|c|c|c|c|c|c|}
\hline & $z$ & 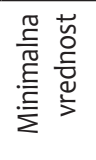 & 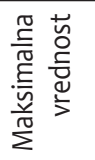 & 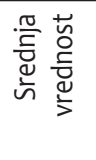 & 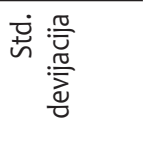 & 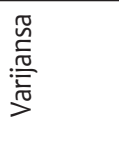 \\
\hline J. ulje & 19 & 1,93 & 143,94 & 62,26 & 48,40836 & 2343,370 \\
\hline S. mast & 19 & 3,90 & 167,06 & 69,21 & 51,80404 & 2683,658 \\
\hline $\begin{array}{l}\text { Broj } \\
\text { validnih N }\end{array}$ & 19 & & & & & \\
\hline
\end{tabular}

Izvor: Autor
Cene analiziranih proizvoda su svedene na one iz 1994. godine, pa je na osnovu tih podataka izvršeno testiranje granica relevantnog tržišta proizvoda.

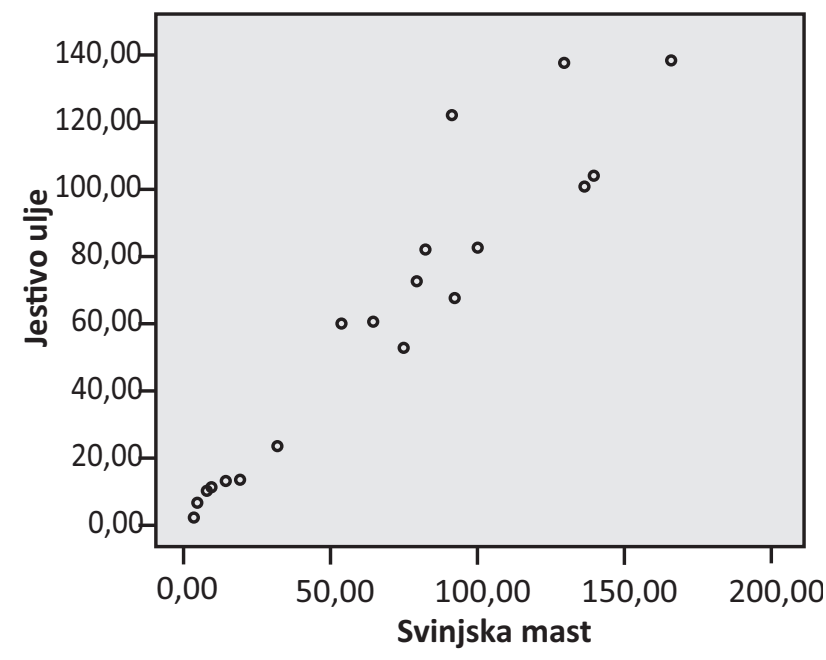

Slika 6 Dijagram rasturanja podataka o kretanju prosečnih tekućih cena na malo jestivog ulja i svinjske masti u periodu 1994-2012.

Izvor: Autor 
Tabela 2 Koeficijent korelacije kretanja prosečnih tekućih cena na malo jestivog ulja i svinjske masti u periodu 1994-2012.

\begin{tabular}{rl|rr}
\hline & & J. ulje & S. mast \\
\hline \multirow{3}{*}{ J. ulje } & $\begin{array}{l}\text { Pirsonov } \\
\text { koeficijent } \\
\text { korelacije } \\
\text { Sig (2-tailed) }\end{array}$ & 1 &, $949^{* *}$ \\
& $\mathrm{~N}$ & 19 &, 000 \\
S. mast & $\begin{array}{l}\text { Pirsonov } \\
\text { koeficijent } \\
\text { korelacije } \\
\text { Sig (2-tailed) }\end{array}$ &, $949^{* *}$ & 19 \\
$\mathrm{~N}$ &, 000 & 1 \\
\hline
\end{tabular}

**Korelacija je signifikantna na nivou 0,01 (2-tailed).

Izvor: Autor

Posmatrajući Sliku 7 može se, kao i u prethodnom slučaju, zaključiti da je kretanje cena analiziranih proizvoda slično, ali u manjoj meri. Postavlja se pitanje da li je to i stvarno tako.
Tabele 3 i 4 i Slika 8 upućuju na zaključak da kretanje cena analiziranih proizvoda nije baš toliko slično koliko se u prvi mah činilo. Na to posebno ukazuje dijagram rasturanja (Slika 8) i na osnovu njega urađena statistička analiza (Tabela 4).

Tabela 3 Deskriptivna statistika podataka o kretanju cena na malo jestivog ulja i svinjske masti u periodu 1994-2012, u cenama iz 1994.

\begin{tabular}{|c|c|c|c|c|c|c|}
\hline & $\mathrm{N}$ & 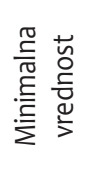 & 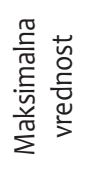 & 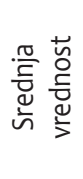 & 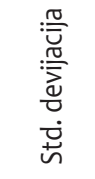 & 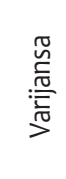 \\
\hline J. ulje & 19 & 1,53 & 2,39 & 1,94 & ,26189 & ,069 \\
\hline S. mast & 19 & 1,51 & 3,90 & 2,37 & 61903, &, 383 \\
\hline $\begin{array}{c}\text { Broj } \\
\text { validnih N }\end{array}$ & 19 & & & & & \\
\hline
\end{tabular}

Izvor: Autor

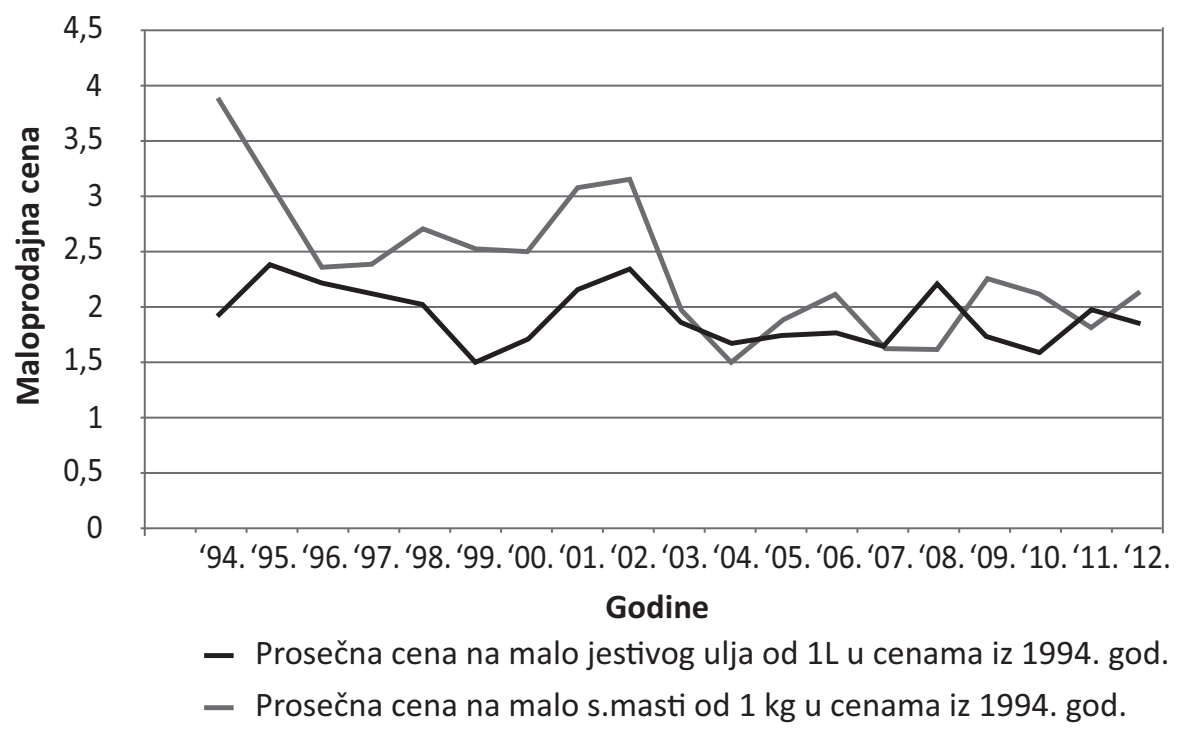

Slika 7 Kretanje cena na malo jestivog ulja i svinjske masti u periodu 1994-2012, u cenama iz 1994. 
Na osnovu stepena korelacije i nivoa značajnosti datih u Tabeli 4 možemo zaključiti da između kretanja cena jestivog ulja i svinjske masti u periodu 1994-2012, u cenama iz 1994, postoji umerena direktna korelaciona veza koja nije statistički značajna, pa sledi zaključak da ova dva proizvoda ne pripadaju istom relevantnom tržištu proizvoda, već da jestivo ulje samostalno konstituiše relevantno tržište proizvoda. Na ovaj način smo potvrdili istraživačku hipotezu H1.

Tabela 4 Koeficijent korelacije kretanja cena na malo jestivog ulja i svinjske masti u periodu 1994-2012, u cenama iz 1994.

\begin{tabular}{ll|rr}
\hline & & J. ulje & S. mast \\
\hline J. ulje & $\begin{array}{l}\text { Pirsonov } \\
\text { koeficijent } \\
\text { korelacije } \\
\text { Sig (2-tailed) }\end{array}$ & 1 &, 410 \\
& $\mathrm{~N}$ & & \\
\hline S. mast & Pirsonov & &, 081 \\
& koeficijent & 19 & 19 \\
korelacije &, 410 & 1 \\
Sig (2-tailed) & & \\
& $\mathrm{N}$ & 17 & 17 \\
\hline
\end{tabular}

Izvor: Autor

\section{Relevantno geografsko tržište}

Relevantno geografsko tržište predstavlja zaokruženu teritoriju na kojoj su slični uslovi konkurencije. Granice relevantnog tržišta određene su korišćenjem LOFI i LIFO testa i dve simulacije: prva je bazirana na podacima iz Statističkih godišnjaka Republike Srbije i sajta http://atlas.media.mit.edu (The Observatory of Economic Complexity) i druga na osnovu podataka dobijenih sa sajta http://www.indexmundi.com/ (Index Mundi). Polazeći od pretpostavke da se za tržište jestivog ulja može uzeti teritorija Republike Srbije kao zaokruženo relevantno tržište, korišćenjem raspoloživih podataka o proizvodnji, potrošnji, izvozu i uvozu testirali smo ovu pretpostavku.

Obe simulacije date $\mathrm{u}$ Tabeli 5 dovode do sličnih rezultata i zaključaka, što potvrđuje njihovu validnost.

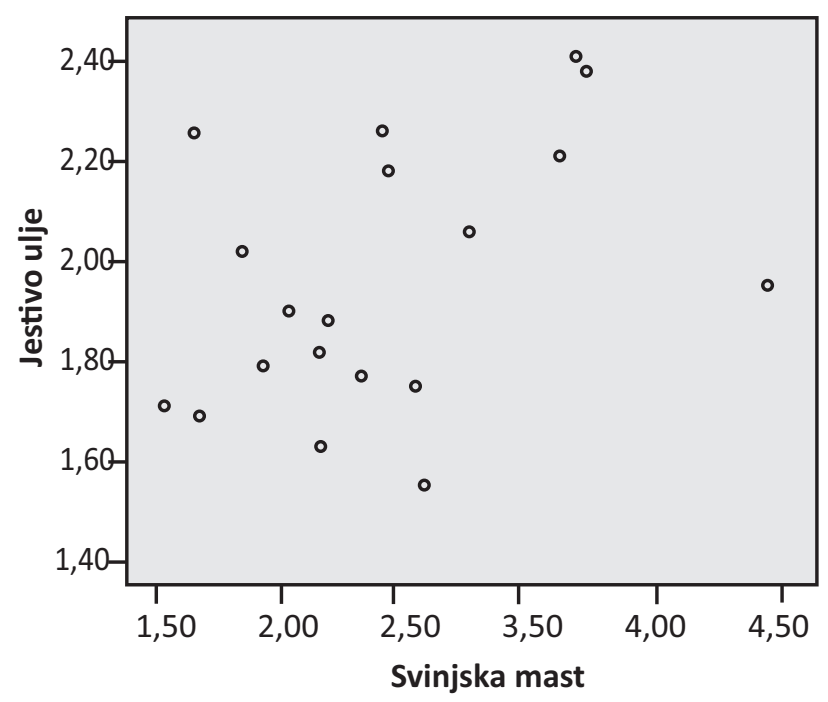

Slika 8 Dijagram rasturanja podataka o kretanju cena na malo jestivog ulja i svinjske masti u periodu 19942012, u cenama iz 1994.

Izvor: Autor

Sa aspekta potrošnje, vrednost LIFO testa upućuje na to da je RS zaokruženo, uglavnom "jako“ relevantno geografsko tržište.

Sa aspekta LOFI testa, tržište RS je u posmatranom periodu uglavnom deo šireg relevantnog tržišta. Međutim, zakonska regulativa zaštite konkurencije, činjenica da RS još uvek nije deo EU i to da po obimu proizvodnje jestivog ulja RS pripada krugu vodećih zemalja regiona, umanjuje značaj LOFI testa. Sledi zaključak da se $u$ ovom istraživanju za relevantno geografsko tržište može definisati teritorija RS. Ovome posebno doprinosi činjenica da su po sličnoj ceni u razgranatoj maloprodajnoj mreži jednako dostupne sve robne marke jestivog ulja proizvedene u domaćim 
firmama. Na ovaj način potvrđena je istraživačka hipoteza $\mathrm{H} 2$.

Tabela 5 LOFI i LIFO test

\begin{tabular}{l|cc}
\hline Godina & LOFI & LIFO \\
\hline \multicolumn{3}{c}{ Simulacija 1 } \\
\hline 2006. & 12,78 & 8,98 \\
2007. & 29,39 & 11,74 \\
2008. & 31,51 & 8,84 \\
2009. & 29,92 & 9,49 \\
2010. & 37,53 & 2,68 \\
\hline \multicolumn{3}{c}{} \\
\hline 2006. & Simulacija 2 \\
2007. & 31,68 & \\
2008. & 35,65 & 15,09 \\
2009. & 35,56 & 6,00 \\
2010. & 57,65 & 5,88 \\
2011. & 45,29 & 4,21 \\
\hline
\end{tabular}

Izvor: Autor

Na osnovu svega napred iznetog može se zaključiti da je relevantno tržište za istraživanje tržišne moći privrednih subjekata koji proizvode jestivo ulje tržište jestivog ulja na teritoriji Republike Srbije. Na ovaj način je potvrđena glavna istraživačka hipoteza i prikazan postupak određivanja granica relevantnog tržišta.

Ovako definisane granice relevantnog tržišta su od izuzetnog značaja za sprovođenje politike zaštite konkurencije, jer omogućavaju pravilnu procenu tržišne moći subjekata koji posluju na njemu, uključivanjem samo onih subjekata koji stvarno utiču na uslove konkurencije. Na taj način je tržište kao relativno širok pojam svedeno na užu, praktičnu dimenziju. To je razlog zbog čega se u razvijenim zemljama vrši testiranje granica relevantnog tržišta i to korišćenjem napred datih i sličnih tehnika ekonomske analize. Sledi da su pomenute tehnike izuzetno bitne za praktično vođenje politike zaštite konkurencije.
U politici zaštite konkurencije RS primena napred navedenih i sličnih tehnika praktično ne postoji. Iako se regulatorni organi deklarativno zalažu za veću primenu ekonomske analize to se ipak ne sprovodi $u$ meri koja je prihvatljiva za savremenu politiku zaštite konkurencije. Definisanje granica tržišta u RS se po pravilu bazira na deskriptivnoj proceni zasnovanoj, pre svega, na iskustvu istraživača, što može da bude polazna osnova analize, ali nikako njen krajnji domet.

\section{ZAKLJUČAK}

Kao što se iz rezultata istraživanja može zaključiti relevantno tržište $u$ obe svoje dimenzije obuhvata jestivo ulje na teritoriji celokupne Republike Srbije. Kao takvo, ono je zaokružena celina u kojoj posluju privredni subjekti čija se tržišna moć može proceniti. Preduslov utvrđivanja tržišne moći je upravo određivanje granica tržišta $u$ kojem se ta moć i ispoljava. Po pravilu, preduzeća koja imaju veliko tržišno učešće imaju i veliku tržišnu moć. Međutim, da bi se tržišno učešće, realizovalo u tržišnu moć mora da postoji sposobnost preduzeća da profitabilno podižu cenu svojih proizvoda.

Sprovedeno istraživanje ima i određena ograničenja, koja svakako ne umanjuju njegov značaj, ali ih je potrebno uvažiti prilikom nove procene dimenzija tržišta. Ograničenja se tiču, pre svega, sprovedenih testova.

Što se tiče Testa korelacije cena problem koji se može javiti kod njegove primene vezan je za pojedine komponente same cene, kao što su transportni i transakcioni troškovi. Ovi sastavni elementi cene mogu u velikoj meri da utiču na nivo korelacije, a teško ih je isključiti. Takođe, postoji i uticaj zajedničkih faktora, koji se teško otklanja, a mogu dovesti do toga da cene proizvoda koji ne pripadaju istom tržištu imaju identično kretanje, pa se može pogrešno zaključiti da pripadaju istom tržištu. Ovako nastala korelacija naziva se prividnom korelacijom, a najčešći zajednički faktor koji utiče na nju je inflacija. U istraživanju je eliminisan uticaj ovog faktora. Veoma značajno ograničenje je i vremensko (ne)poklapanje podataka o kretanju cena analiziranih proizvoda. Dešava se da promena cene jednog proizvoda utiče na promenu 
cene drugog proizvoda sa određenim vremenskim kašnjenjem i, kada se uključi ovo kašnjenje, dolazimo do vrednosti korelacije koja upućuje na to da se (ili ne) radi o proizvodima koji pripadaju jedinstvenom tržištu (Slade, 1986, 293). U sprovedenom istraživanju nije uključeno vremensko kašnjenje zbog toga što se radi o godišnjim podacima, pa uključivanje nema velikog smisla.

Na drugoj strani, Test fizičkog kretanja proizvoda je kritikovan zbog pojednostavljenog shvatanja geografskog tržišta. Prisustvo kretanja dobara između oblasti često nije dovoljan uslov da se za neko tržište tvrdi da je deo jedinstvenog tržišta (Stigler \& Sherwin, 1985, 580). Može se desiti da dođe do značajnog kretanja potrošača između teritorija, što je dokaz postojanja jedinstvenog tržišta. Proizilazi da kod određivanja geografskih granica tržišta, pored mobilnosti dobara, treba proučavati i mobilnost kupaca. Ovo se naročito odnosi na uslužne delatnosti, gde je test zbog karakteristika dobara primenljiv u ograničenom opsegu (Elzinga \& Swisher, 2011, 143). Takođe, tu je i problem vezan za zajedničko uključivanje kretanja gotovih proizvoda, poluproizvoda i sirovina. Uobičajeno je da se zbog praktičnosti uzima samo kretanje finalnih proizvoda, a ne i poluproizvoda i sirovina, iako njihovo kretanje može upućivati na pravce kretanja finalne ponude. Tu je i problem kretanja proizvoda zbog različitih cena između teritorija. Treba voditi računa da u slučaju da su cene različite, proizvodi uvek idu ka regionu gde je cena viša sve dok se cene ne izjednače. Analiza protoka dobara u trenutku kada su cene različite može stvoriti pogrešnu sliku o povezanosti dve oblasti. Zbog toga je preciznija analiza ona koja se sprovodi kada su cene izjednačene i stabilne među regionima. Značajan je i problem asimetričnog kretanja dobara između regiona, odnosno, situacija u kojoj region više izvozi nego što uvozi nekih proizvoda. Taj problem je postojao i u sprovedenom istraživanju, ali je otklonjen većim naglaskom na uvozu dobara.

Pored ograničenja vezanih za testove, mogu se navesti i ograničenja vezana za sprovedeno istraživanje. Pored sekundarnih podataka, za potrebe određivanja granica tržišta mogu se koristiti i primarni podaci dobijeni putem anketa, gde se potrošači izjašnjavaju o zamenljivosti analiziranih proizvoda. Takođe, oni se mogu izjasniti i o stepenu vezanosti za domaće marke proizvoda. Takva analiza može da bude dopuna prethodnim testovima. Takođe, serija prikupljenih podataka bi u perspektivi mogla da bude duža što bi obezbedilo veću validnost sprovedenog istraživanja.

Bez obzira na sva ograničenja i probleme, pomenuti testovi su izuzetno korisni i predstavljaju praktičnu osnovu za određivanje granica tržišta. U tom svetlu, treba shvatiti ovaj rad, kao ukazivanje na potrebu veće primene ekonomske analize $u$ segmentu zaštite konkurencije. To je trend $u$ razvijenim ekonomijama (SAD i EU), gde je svaka odluka, usmerena na sankcionisanje nekonkurentne prakse, bazirana na ekonomskoj analizi, i to od definisanja granica tržišta do sagledavanja posledica takvog ponašanja i mera za njegovo otklanjanje.

Primena ekonomske analize je naročito značajna $u$ sferi definisanja granica tržišta, jer se na taj način $u$ krajnoj liniji određuje prostor na kome se proučavaju uslovi konkurencije. Politici zaštite konkurencije u RS nedostaje upravo ovakva ekonomska analiza. Pristup zasnovan na faktografskom tumačenju članova zakona, nije dovoljan. Svaku odluku treba potkrepiti i ekonomskom analizom. Dobar put za to bi moglo biti uvođenje $\mathrm{u}$ zakonske i podzakonske akte obaveze primene konkretnih testova određivanja granica tržišta.

Što se tiče daljih istraživanja, ona će biti vezana za praktičnu razradu problematike relevantnog tržišta i određivanja njegovih granica, posebno, otklanjanje ograničenja na koje je naišla ova analiza. Značajna pažnja će biti usmerena i na procenu tržišne moći korporacija primenom odgovarajućih pokazatelja koncentracije $\mathrm{i}$ nejednakosti u raspodeli tržišnog učešća.

\section{REFERENCE}

ABA (2005). Market Power Handbook. USA: American Bar Assocation, Sector of Antitrust Law.

ACPC (2009). Glosar termina koji se koriste u politici konkurencije Evropske unije - Antimonopolsko pravo i kontrola konkurencije. Beograd, Srbija: Tehnička pomoć Komisiji za zaštitu konkurencije. 
Cartwirght, P. A., Kamerschen, D. R., \& Huang, M. Y (1989). Price Correlation and Granger Causality Tests for Market Definition. Review of Industrial Organization, 4(2), 79-98. doi: 10.1007/BF02284670

Coate, B. M., \& Simons, J. J (2012). In Defense of Market Definition. Antitrust Bulletin, 57(4), 667-717.

DOJ \& FTC (2010). Horizontal Merger Guidelines. USA: U.S. Departement of Justice and the Federal Trade Commission.

DOJ (n.d.). U.S. Department of Justice. Preuzeto 09.09.2012. sa http://www.justice.gov/atr/public/health_care204694/ chapter4.htm\#N37

EBRD (n.d.). Preuzeto 16.10.2012. sa http://www.ebrd.com/ pages/research/economics/data/macro.shtml\#macro

EBRD (n.d.) Preuzeto 30.03.2014. sa http://www.ebrd.com/ downloads/research/REP/rep-may-2013.pdf

EBRD (n.d.) Preuzeto 30.03.2014. sa http://www.ebrd.com/ downloads/research/REP/regional-economic-prospects1210. pdf

Elzinga, K., \& Hogarty, T (1973). The Problem of Geographic Market Definition in Antimerger Suits USA. Antitrust Bulletin, 18(1), 45-81.

Elzinga, K. G., \& Swisher, A. W (2011). Limits of the ElzingaHogarty Test in Hospital Mergers: The Evanston Case. International Journal of the Economics of Business, 18(1), 133-146. doi: 10.1080/13571516.2011.542963

European Union (1997). Commission Notice on the Definition of the Relevant Market for the Purposes of Community Competition Law. Official Journal of European Union.

Geroski, P. A (1998). Thinking creatively about markets. International Journal of Industrial Organization, 16(6), 677-695.

Index Mundi (n.d.). Preuzeto 16.10.2012. sa http://www. indexmundi.com

Juselius, M., \& Stenbacka, R (2011). The Relevant Market for Production. Scandinavian Jouranl of Economics, 113(1), 167-189. doi: 10.1111/j.1467-9442.2010.01640.x

Kaplow, L (2012). Market definition alchemy. Antitrust Bulletin, 57(4), 915-952.

Kostić, M (2007). Merenje koncentracije ponude grane. Ekonomski horizonti, 9(1-2), 89-108.
Kostić, M (2012). Značaj relevantnog tržišta za kvalitetnu procenu uslova konkurencije. U V. Leković (Red.), Institucionalne promene kao determinanta privrednog razvoja Srbije (249-260). Kragujevac: Ekonomski fakultet Univerziteta u Kragujevcu.

Labus, M (2008). Uporedna analiza relevantnog tržišta koncept i primena. Ekonomika preduzeća, 56(1-2), 48-60.

Lopatka, E. J (2011). Market Definition? Review of Industrial Organization, 39(1-2), 69-93. doi: 10.1007/s11151-011-9302-z

Massey, P (2000). Market Definition and Market Power in Competition Analysis: Some Practical Issues. The Economic and Social Review, 31(4), 309-328.

Motta, M (2008). Competition Policy: Theory and Practice. Cambridge, UK: Cambridge University Press.

Republički zavod za statistiku Srbije (1995-2013). Statistički godišnjaci od 1994-2012. Beograd: Republički zavod za statistiku Srbije.

Republika Srbija (2009). Zakon o zaštiti konkurencije. Službeni glasnik Republike Srbije br. 51/09.

Slade, M. E (1986). Exogeneity Tests of Market Boundaries Applied to Petroleum Products. Journal of Industrial Economics, 34(3), 291-303.

Stadler, S. K (2009). Relevant Markets for Copyrighted Works Journal of Corporation Law. Journal of Corporation Law, 34(4), 1059-182.

Stigler, G. J., \& Sherwin, R. A (1985). The Extent of the Market. Journal of Law and Economics, 28(3), 555-585.

The Observatory of Economic Complexity (n.d.). Preuzeto 06.10.2012. sa http://atlas.media.mit.edu

Vuković, B. D (2013). Korelaciona analiza indikatora regionalne konkurentnosti: Primer Republike Srbije. Ekonomski horizonti, 15(3), 197-211. doi: 10.5937/ekonhor1303197V

Werden, G. J (1992). The History of Antitrust Market Delineation. Marquette Law Review, 76 (1), 123-215.

Xianlin, W (2008). On Defining Relevant Markets in Implementing the Antimonopoly Low of China. Frontiers of Law in China, 3 (4), 540-555. doi: 10.1007/s11463-008-0026-4 
Primljeno 3. marta 2014, nakon revizije, prihvaćeno za publikovanje 17. aprila 2014.

Milan Kostić je docent u užoj naučnoj oblasti Opšta ekonomija i privredni razvoj na Ekonomskom fakultetu Univerziteta u Kragujevcu, na nastavnom predmetu Teorija i politika cena. Doktorirao je u užoj naučnoj oblasti Mikroekonomija - Industrijska organizacija, na Ekonomskom fakultetu Univerziteta u Kragujevcu. Bavi se istraživanjima iz oblasti zaštite konkurencije, definisanja granica relevantnog tržišta, stepena ograničenosti tržišta, potrošačkog etnocentrizma i privatizacije. 
DODATAK

Tabela 1 Kretanje prosečnih tekućih cena, inflacije i korigovanih cena jestivog ulja i svinjske masti u periodu 1994-2012, u Republici Srbiji

\begin{tabular}{|c|c|c|c|c|c|}
\hline Godina & $\begin{array}{l}\text { Prosečna cena na } \\
\text { malo jestivog ulja } \\
\text { od } 1 \text { l }\end{array}$ & $\begin{array}{c}\text { Prosečna cena na } \\
\text { malo sv. masti od } \\
1 \mathrm{~kg}\end{array}$ & Godišnja inflacija u \% & $\begin{array}{l}\text { Prosečna cena na } \\
\text { malo jestivog ulja od } \\
\text { 1l u cenama iz } 1994 .\end{array}$ & $\begin{array}{c}\text { Prosečna cena na } \\
\text { malo sv. masti od } 1 \\
\text { kg u cenama iz } 1994 .\end{array}$ \\
\hline 1994. & 1,93 & 3,90 & - & 1,93 & 3,90 \\
\hline 1995. & 4,26 & 5,61 & 78,60 & 2,39 & 3,14 \\
\hline 1996. & 7,78 & 8,25 & 94,30 & 2,24 & 2,38 \\
\hline 1997. & 8,85 & 9,84 & 18,30 & 2,16 & 2,40 \\
\hline 1998. & 10,89 & 14,50 & 30,00 & 2,04 & 2,72 \\
\hline 1999. & 11,53 & 19,10 & 41,10 & 1,53 & 2,54 \\
\hline 2000. & 22,12 & 32,18 & 70,00 & 1,73 & 2,51 \\
\hline 2001. & 53,65 & 75,63 & 91,80 & 2,19 & 3,08 \\
\hline 2002. & 69,23 & 93,21 & 19,50 & 2,36 & 3,18 \\
\hline 2003. & 61,65 & 65,39 & 11,70 & 1,88 & 2,00 \\
\hline 2004. & 61,14 & 54,50 & 10,10 & 1,69 & 1,51 \\
\hline 2005 & 74,30 & 80,06 & 16,50 & 1,77 & 1,90 \\
\hline 2006. & 85,13 & 101,13 & 12,70 & 1,80 & 2,13 \\
\hline 2007. & 84,36 & 83,15 & 6,50 & 1,67 & 1,65 \\
\hline 2008. & 127,03 & 92,32 & 12,40 & 2,24 & 1,63 \\
\hline 2009. & 107,14 & 140,18 & 8,10 & 1,75 & 2,29 \\
\hline 2010. & 104,65 & 138,31 & 5,70 & 1,61 & 2,13 \\
\hline 2011. & 143,94 & 130,69 & 11,10 & 2,00 & 1,82 \\
\hline 2012. & 143,34 & 167,06 & 7,30 & 1,86 & 2,16 \\
\hline
\end{tabular}

Izvor: Autor, na osnovu podataka iz Statističkih godišnjaka R. Srbije od 1994. do 2012, sajta http://www.ebrd.com/pages/research/ economics/data/macro.shtml\#macro, preuzetog 16.10.2012, sajt http://www.ebrd.com/downloads/research/REP/rep-may-2013. pdf, preuzetog 30.03.2014. i sajt http://www.ebrd.com/downloads/research/REP/regional-economic-prospects1210.pdf, preuzetog 30.03.2014. 


\title{
TESTING THE BOUNDARIES OF THE RELEVANT MARKET IN THE COMPETITION POLICY
}

\author{
Milan Kostic \\ Faculty of Economics, University of Kragujevac, Kragujevac, Serbia
}

\begin{abstract}
The concept of the relevant market is very important for the competition policy. The assessment of the market power of the economic entities operating on a relevant market depends on the market size. The relevant market has two dimensions - the production and the geographic ones - hence, there are a relevant product market and a relevant geographic market. The purpose of the paper is to show the possible ways of determining the relevant market boundaries, in an explicit and systematic way, by applying appropriate tests, and on the example of the specific Serbian market. In the paper, two important tests to determine the boundaries of the market have been applied: the Price Correlation Test and the Goods Physical Movement Test (the Elzinga-Hogarty test). The tests are very useful in situations where researchers only possess secondary data and want to determine the boundaries of the market based on them. The disadvantages of the tests, which of course exist, do not diminish their importance; therefore, they are very useful and recommended for determining the scope of the market.
\end{abstract}

Keywords: relevant market, competition policy, Price Correlation Test, Elzinga-Hogarty test

JEL Classification: D47, L40, K21 